\title{
Diplomatic relations between the Ottoman Empire and the Ukrainian Democratic Republic, 1918-21
}

\section{Hakan Kirimli}

To cite this article: Hakan Kirimli (1998) Diplomatic relations between the Ottoman Empire and the Ukrainian Democratic Republic, 1918-21, Middle Eastern Studies, 34:4, 201-239, DOI: $10.1080 / 00263209808701249$

To link to this article: https://doi.org/10.1080/00263209808701249

册Published online: 06 Dec 2006.

6 Submit your article to this journal 줄

Џ Article views: 95 


\title{
Diplomatic Relations between the Ottoman Empire and the Ukrainian Democratic Republic, 1918-21
}

\author{
HAKAN KIRIMLI
}

The signing of the Treaty of Brest-Litovsk between the Central Powers and the newly-born Ukrainian Democratic Republic (Ukrayins'ka Narodnia Respublika) $)^{1}$ on 9 February 1918 was the first step in ending the war on the 'Eastern Front'. This was to be formalized with the following treaty with Soviet Russia, though various forms of military actions on the European parts of the territory of the former Russian Empire went on for over two years. The Ukrainian Treaty of Brest-Litovsk was the first diplomatic recognition of independent Ukraine in modern times. It was to be the subsequent military actions of the Central Powers (particularly those of Germany) in accordance with this treaty which would secure the new independent Ukrainian state from being annihilated by the Bolsheviks. At the time when the representatives of the Ukrainian Democratic Republic signed the Treaty of Brest-Litovsk with the Central Powers, almost all of the territory of the new republic was already under Bolshevik invasion. The treaty of Brest-Litovsk between the Central Powers and the Ukrainian Democratic Republic, which was literally cornered by the Bolshevik invasion of the country, enabled the latter not only to accomplish its first diplomatic relations but virtually to reclaim most of Ukraine thanks to the German and Austro-Hungarian arms.

In fact, the cause of Ukrainian independence had already been introduced to the Central Powers during the initial phase of the First World War, through the activities of Ukrainian nationalist organizations, especially those of the 'Union for the Liberation of Ukraine' (Soyuz Vyzvolennya Ukrayiny). Germany and Austria-Hungary had offered, at times quite generous sponsorship to the activities of the 'Union for the Liberation of Ukraine'. The issue of creating an independent Ukraine was discussed at length by the Germanic Powers, however no clearcut strategy was adopted. ${ }^{2}$ Nevertheless, it was with the Treaty of Brest-Litovsk in February 1918 that the independence of Ukraine became a political and diplomatic reality. This 
process also applied to the Ottoman Empire where the Union for the Liberation of Ukraine, through German and Austro-Hungarian diplomatic circles, had engaged in certain activities especially in 1914-15.

At Brest-Litovsk, at a time when the negotiations with the Bolshevik representatives reached virtual deadlock, the dignitaries of the Central Powers opted to sign a separate treaty with the representatives of the government of the 'Ukrainian Democratic Republic' who represented a country most of which at that time was effectively controlled by the Bolsheviks. ${ }^{3}$ Like their allies, the Ottomans too approved the conclusion of a separate truce with the Ukrainians. Apart from vital economic considerations, such as those concerning the grain provisions from the Ukraine, the Central Powers viewed an independent (and, of course, a 'benevolent') Ukraine as a bulwark against the Bolshevik menace, as well as a further device to force intransigent Soviet Russia to accept peace on their own terms.

Having recognized the importance of the factors concerning the Central Powers in general, the Ottoman delegation at Brest-Litovsk headed by the Grand Vizier Talât Pasha had its own notion of the emergence of an independent Ukraine. No doubt, the most important implication of Ukrainian independence for the Turks was that the historical 'Muscovite' threat to the Ottoman Empire was to be effectively removed by such a buffer state, which was expected to be a friendly one. The Ottoman delegation met privately with their Ukrainian colleagues on 17 January 1918. Though the meeting was conducted in a markedly warm atmosphere, the Ukrainian side especially did not have much to say in concrete terms due to the uncertainties surrounding the new and volatile Ukrainian state. At this meeting, the Ottomans expressed special concern about the southern boundaries of Ukraine and the question of the possession of the former Russian Black Sea Fleet. On their part, the Ukrainians brought forward the issue of the free passage through the Turkish Straits, which the Ottomans promised to grant to commercial ships during peace time, though certain restrictions would be imposed in times of war. ${ }^{4}$

Talât Pasha, as he cabled to the Ottoman Generalissimo Enver Pasha on 1 February 1918, hoped that Ukrainian independence would permit the establishment of Muslim governments in the Crimea and the Caucasus. The news which he had received from the Crimean Tatars who had indeed formed a national parliament (Kurultay) and a government, encouraged the Grand Vizier to think this way. ${ }^{5}$ He was convinced that, their rhetoric notwithstanding, the Bolsheviks intended to recreate the former Great Russia and were trying to prevent the break-away nations from declaring independence, as was proven by the cases of Ukraine and Finland. Talât Pasha also favoured the liberation of the Ukrainian lands from the 
Bolsheviks by sending German troops and, for that purpose, the finding of a 'Ukrainian Venizelos' who would call in the Central Powers. He considered the Rada Ukrainian representatives who were at Brest-Litovsk 'unfit to take great decisions'.

Consequently, the Treaty of Peace between Ukraine and the Central Powers was signed on 9 February 1918 at Brest-Litovsk. ${ }^{7}$ Among other matters, the Treaty called for the commencement of diplomatic relations between the parties, the mutual renunciation of the payment of war costs and damages, the exchange of prisoners, and, of course, the immediate opening and regulation of economic relations, which was the exigent concern of the Germanic Powers. The special paragraph related to the economic relations between the Ottoman Empire and Ukraine read:

In regard to the economic relations between the Ottoman Empire and the Ukrainian Democratic Republic, these shall, until such time as a definitive Commercial Treaty shall have been concluded, be regulated on the basis of most-favoured-nation treatment. Neither party shall lay claim to the preferential treatment which the other party has granted or shall grant to any other State arising out of a present or future Customs Union, or arising in connection with petty frontier intercourse. $^{8}$

Being the first (and victorious) peace treaty of the exhausting three-anda-half-year war, the Ottoman parliament (Meclis-i Mebusân) acclaimed the Peace Treaty with Ukraine. While reporting on the Treaty, Ahmed Nesîmî1 Bey, the Foreign Minister, defended its conditions by pointing out the concomitant economic advantages to the Central Powers. He said, in accordance with the Treaty, starting from that year Ukraine would be 'obliged to sell its surplus [grain] production which was estimated in great numbers as well as several agricultural, industrial and military products such as livestock, coal, and iron to the Allies.' This was a blow to the economic blockade which the Entente was boasting to have imposed on the Central Powers. ${ }^{9}$

As for the Ottoman public and press, in fact, the very concept of an independent country called Ukraine was a novelty. The overwhelming majority of the learned stratum of Ottoman society was virtually oblivious to the presence of a people called Ukrainians as separate from Russians. Still, Ukrainian independence received a warm welcome in the Ottoman Empire. For many, such an occurrence represented the end of the 'Muscovite menace' from the north. At a time when, after an extremely devastating and costly war, the Ottoman front against Russia was in shambles, all of a sudden not only did the Russian Empire collapse, but seemingly great prospects in the north and east emerged from among the 
ruins of the Russian Empire. Tanin, the unofficial mouthpiece of the ruling Union and Progress Committee, applauded this first peace treaty since it would put pressure on both Russia and Romania to conclude peace treaties. Tanin saw Ukraine as a potential ally of the Ottoman Empire. ${ }^{10}$

Following the signing of the peace treaty, it did not take long for diplomatic relations between the Ottoman Empire and Ukraine to be forged. The Ukrainian government appointed Mykola Levyts'kyi, a member of the Central Rada and the Ukrainian delegate at Brest-Litovsk, as the Ukraine's temporary resident in Istanbul. The Ottoman government was informed of this on 8 April 1918 and it duly recognized his office. ${ }^{11}$ Before he came to Istanbul, Levyts'kyi, together with his secretary Mykola Vuchenko, visited the Ottoman Ambassador in Vienna on 17 April. ${ }^{12} \mathrm{He}$ arrived in Istanbul on 19 April, accompanied by his family and Vuchenko. ${ }^{13}$ Three days later he visited Talât Pasha and some other ministers. ${ }^{14}$ Levyts'kyi's mission attracted the attention of the Ottoman press. Expressing pleasure at the presence of a representative of independent Ukraine in Istanbul 'as the most vivid and brightest evidence of a great victory which had been won over a centuries-old enemy [Russia]', Tanin's editorial assessed the new geopolitical situation particularly in the context of the issues of the Black Sea and the Straits. Having referred to the long-standing ambitions of Tsarist Russia over the Straits, the editorial pointed out the historical irony that it was due to the successful defence of the Straits by the Turks that the Russian Empire had collapsed and the new Ukraine had been born. ${ }^{15}$

Levits'kyi's arrival in Istanbul coincided with an atmosphere of growing concern among the Ottoman public and press for the fate of the Crimea and the Crimean Tatars. In fact, for a long time, the Ottomans had been virtually oblivious to post-Russian Revolution events in the Crimea. Therefore, the convocation of the Crimean Tatar National Parliament (Kurultay), ${ }^{16}$ its adoption of a Constitution which declared the principle of the 'Crimean Democratic Republic' and the establishment of its rule over most of the peninsula (except for the Bolshevik-held Sevastopol) throughout December 1917 had all taken place without drawing the attention of the Turkish press. This was the case too with the defeat of the Crimean Tatar troops by the Bolsheviks and the latter's invasion of the Crimea and the accompanying atrocities during the second half of January $1918 .{ }^{17}$ It was only from the second half of March 1918 that the Ottoman press, as well as Ottoman officialdom, began to be informed about the nature of the events in the Crimea through the arrival of a few Crimean Tatar refugees, most prominent of whom was Cafer Seydahmet [Kırımer], the Foreign and War Minister (Director) of the Crimean Tatar National Government. ${ }^{18}$ From late March, the Ottoman press carried an ever-increasing number of news items and commentaries about the Crimea, most of which called for the adoption of 
exigent measures to help the Crimean Tatars whose independence the Bolsheviks had violently quashed. The beginning of the German occupation of the Crimea on 19 April 1918, and the arrival of Cafer Seydahmet in Istanbul on 20 April $^{19}$ further invigorated the public's pro-Crimean Tatar stand.

Certainly, this current issue proffered a novel but critical dimension to the Ottoman public in its contemplation of Black Sea matters in general and Ukrainian problems in particular. It was obvious that the stance of Ukraine vis-à-vis Crimean (Tatar) independence would be crucial. These developments were the first indications that the Crimean factor would be a cardinal issue in determining Turko-Ukrainian relations. This was the political atmosphere which Levyts'kyi encountered on his arrival in Istanbul. It is not surprising that in his very first interview with the Turkish press one of the central questions put to Vuchenko concerned the position of Ukraine in regard to the Crimean events. Vuchenko, understandably, tried to avoid giving a direct answer by referring to the presence of non-Muslims in the Crimea as well as Muslims, and Ukraine's respect for other nationalities. He also stated that Levyts'kyi's mission was a temporary one, in anticipation of the establishment of regular and permanent diplomatic missions. ${ }^{20}$ Vuchenko's statements about the Crimea did not satisfy the Ottoman public. Tanin's editorial was politely critical of Vuchenko and 'some new and inexperienced politicians of Ukraine', and expressed hopes of a better understanding and appreciation of Crimean (Tatar) independence among Ukrainian circles. ${ }^{21}$

As a matter of fact, until the end of the First World War the Crimean issue was to remain central to the Ottoman Turkish public in assessing the relations with Ukraine. The newly established government of Hetman Pavlo Skoropads'kyi brought forward claims over the Crimea, which had been under German military occupation from late April 1918. A concrete manifestation of these démarches was the Ukrainian Foreign Minister Dmytro Doroshenko's official demand, in early May 1918, to Philip Alfons Mumm Baron von Schwartzenstein, the German Ambassador in Kiev, to annex the peninsula to Ukraine on the grounds of 'economic and maritime necessities'. ${ }^{22}$ These claims were vehemently opposed by the Crimean Tatars. The Crimean Tatar National Administration (Milli İdare), which was to use the power of the Kurultay between the latter's sessions and which was allowed by the German occupational regime to handle Crimean Tatar matters, appealed to the Ottoman government and public. For this purpose, Yakup Kemal and Üseyin Badaninskiy, members of the Kurultay and leading intellectuals, were sent to Istanbul. The Crimean Tatar representatives arrived in Istanbul on 16 June $1918,{ }^{23}$ and they were received by Enver Pasha on 18 June..$^{24}$ Apart from their verbal explanations, 
they presented a note of protest the full text of which was published by Istanbul papers. ${ }^{25}$ Yakup Kemal and Üseyin Badaninskiy also visited the German and Bulgarian ambassadors in Istanbul and brought their cause to their attention and, in all likelihood, presented the note of protest. Apparently they were received with sympathy, though a cautious one, by the diplomats. While Johann von Bernstorff, the German Ambassador, assured them that 'Germany would support the organization of the Crimea as an independent state', the Bulgarian Ambassador stated that, in accordance with the principle of self-determination embraced by Bulgaria, his government would consider the demands of the Crimeans as just. ${ }^{26}$

The Crimean Tatar deputation's presence in Istanbul occasioned renewed vigour in the pro-Crimean stand of the Ottoman press. The influential Tanin, among others, strongly condemned Ukrainian ambitions. Its lengthy editorial entitled 'The Crimea and Ukraine' pointed out the irony that while the young Ukrainian state owed its very existence to the principle of self-determination, it denied the application of this principle to other peoples. The editorial stressed that the Ottoman Empire 'certainly could not remain aloof to the destiny of [the Crimean Tatars] with whom we were tied by bonds of race, religion, and history'. ${ }^{27}$ The pro-Crimean campaign of the Ottoman press did not go unnoticed by the German press. RheinischWestfälische Zeitung cited excerpts from them in its commentary. ${ }^{28}$

On 1 August 1918 Hasan Sabri Ayvazov, a well-known figure in the Crimean Tatar National Movement and the Chairman of the Kurultay, arrived in Istanbul in the capacity of 'Diplomatic Representative of the Crimean Government'. ${ }^{29}$ Ayvazov's mission was basically arranged by Cafer Seydahmet, who was then the Foreign Minister of the Crimean Regional Government. It was the Ukrainian blockade which prompted the dispatch of a resident Crimean envoy to the Ottoman capital. On his arrival in Istanbul, Ayvazov stated that his aim was to obtain recognition of the independence of the Crimea. ${ }^{30}$ Like the previous Crimean Tatar representatives in Istanbul, Ayvazov, already a renowned figure in Ottoman intellectual and political circles, was also received warmly. During his stay in Istanbul he worked assiduously to enlist Ottoman support to prevent a Ukrainian annexation of the Crimea and to end the Ukrainian economic embargo. Apparently, he was on very intimate terms with the Ottoman statesmen, including Enver Pasha. ${ }^{31}$ At the same time, Ayvazov made use of the Ottoman press to publicize the Crimean cause. ${ }^{32}$

In early September 1918 Talât Pasha, the Ottoman Grand Vizier, visited Berlin with a full agenda to talk to German statesmen at a time when Ottoman efforts to continue the war were rapidly being exhausted. His visit coincided with that of Hetman Pavlo Skoropads'kyi, who was there to meet the Kaiser. Though the Ottoman and Ukrainian dignitaries did not meet in 
the German capital, they had certain common issues which they were to discuss with the Germans. The most important was the future of the Crimea (albeit this was by no means a matter of primary concern, especially on the agenda of the Grand Vizier). In fact, Cafer Seydahmet, together with Count V.S. Tatishchev, Crimean Minister of Finance, had already been there for a month. Though the Germans were rather ill at ease with the presence and activities of the Crimean delegation, especially the hand-in-glove relations of Cafer Seydahmet with the Ottoman diplomats and statesmen in Berlin, they were tolerated up to a point, apparently due to this very relationship. On Talât Pasha's arrival, Cafer Seydahmet asked him to help iron out their differences with the German authorities concerning recognition of the independence of the Crimea. Talât Pasha, during his meeting with Paul von Hintze, the German Foreign Minister, raised the issue, but in view of many more urgent matters for the Ottoman Empire he was in no position to push it further. ${ }^{33}$ As a matter of fact, neither the Hetman nor the Crimeans nor the Ottomans achieved what they had hoped for the future of the Crimea. Although the Germans refrained from giving a free hand to Skoropads'kyi in annexing the Crimea immediately, during the ensuing months before the end of the war they made it clear that they favoured a union between Ukraine and the Crimea. ${ }^{34}$ At any rate, the Crimean question could not be solved in favour of either Ukraine or the Crimean Tatars, as all of these political actors were withdrawn from the scene soon after the defeat of the Central Powers.

Thus, from spring 1918 until the end of the First World War, the question of the Crimean Tatars was a matter of quite sensitive concern on the part of the Ottoman public. These feelings rose high during the Ukrainian-Crimean crisis of summer 1918. Though the Ottoman Empire did not (and could not) take much concrete action in the diplomatic and military field to display its support for the Crimean Tatars, there were cordial relations between the leaders of the ruling Union and Progress and those of the Crimean Tatar National Kurultay (many of whom were old acquaintances anyway). Yet, even when the harshest critics of Skoropads'kyi's regime on the grounds of the encroachments against Crimean independence and the economic blockade appeared in the Ottoman press, these critics never went beyond the matter at issue and the indispensability of a firm and enduring friendship between Turkey and Ukraine was always underscored simultaneously. As for the Ottoman statesmen, they considered an independent Ukraine indispensable in the context of a friendly Black Sea region which included equally essential independence for Turkey's ethno/religious brethren in the Crimea and Northern Caucasus. In any case, the prevailing differences of opinion over the Crimean question did not impede the establishment of good relations between the two countries. 
A practical issue in Ottoman-Ukrainian relations was the exchange of prisoners of war and internees as required by the Treaty of Brest-Litovsk. Such Ukrainians within the Ottoman Empire had already appealed to Turkish officialdom to be allowed to return to their countries no later than early May $1918^{35}$ (Levyts'kyi should have brought forward the subject to the Ottoman Foreign Ministry too). On 3 June 1918 the Ottoman government resolved that, in accord with the stipulations of the Treaty, the interned Ukrainian civilians would be released and those who desired to return to their homeland would be allowed to do so by ship to Odessa. The Ottoman government was to undertake the transportation expenses of those who did not have the material means to travel. ${ }^{36}$ As for the military prisoners of war, as required by the Treaty of Brest-Litovsk, special commissars were to be appointed by both governments to handle their release but these appointments had not been made by mid-August 1918. Also, it was deemed necessary first to examine the reciprocal procedure concerning Ottoman prisoners of war in Ukraine through the Ottoman representatives there. ${ }^{37}$ One problem which arose from dealing with the 'Ukrainians' detained in Ottoman Empire was that of authenticating their 'Ukrainianness', as all of them had been interned or taken prisoner as subjects of the former Russian Empire. Therefore, a careful investigation of the 'Ukrainians' was necessary lest non-Ukrainians (i.e. Russians) infiltrated them.

During the final spring and summer of the First World War, Istanbul turned into a very lively centre for lobbying and meeting for many a political figure and diplomat from the territories of the ex-Tsarist empire, especially from the Caucasus, who sought the most advantageous partition of what was left of the former Russian Empire for the peoples they represented. Indeed, several Turkish and foreign circles in Istanbul were constantly discussing the future of the Caucasus, Balkans, Bessarabia, the Crimea, Turkestan, and other lands of the region. Levyts'kyi found himself in the midst of these discussions and lobbies. He became acquainted with many of the men including the Ambassador of Persia in Istanbul to whom Levyts'kyi attributed a special importance. Most likely, this constituted the first official contact between Ukraine and Persia. The representatives of the North Caucasian Muslims or those of the North Caucasian Republic were of particular concern to Levyts'kyi. Apparently, the latter was singularly perturbed by the North Caucasian Muslims' territorial claims including territories as far north as Kuban River which the Ukrainian envoy regarded as belonging to the Kuban Cossacks who were of Ukrainian (i.e. Zaporozhian) stock. ${ }^{38}$

The Ottoman diplomatic missions to Ukraine were established soon after the ratification of the Treaty of Brest-Litovsk. In fact, Fahreddin Bey, the pre-war Ottoman chargé d'affaires to St Petersburg, had already been 
appointed as the temporary resident to Kiev in June $1918 . .^{39}$ The establishment of the permanent Ottoman mission in Kiev, however, took place with the appointment of Ahmet Muhtar Bey, an experienced diplomat and the former Ottoman Ambassador in Greece. ${ }^{40}$ Having been received by the Sultan on 1 September 1918, ${ }^{41}$ Ahmet Muhtar Bey soon set out for Kiev. The arrival of the Ottoman Ambassor in the Ukrainian capital was welcomed by the Ukrainian press, which stressed the importance of TurkoUkrainian relations. ${ }^{42} \mathrm{He}$ was ceremoniously received by Hetman Skoropads'kyi on 12 October 1918. In the reciprocal speeches during the ceremony, the historical roots of the Ottoman-Ukrainian friendship and hopes for the future were set forth. ${ }^{43}$ Ahmet Muhtar Bey, in his complicated task of establishing the Ottoman mission in Kiev, found an unexpected associate in the person of Abdürreşid İbrahim sometime in late October 1918. The latter, a Siberian Tatar and one of the most important political figures of the Turkic Muslims of the Russian Empire at least during the last two decades of Tsardom, happened to return from Hungary to Istanbul via Kiev, and upon a directive from the Ottoman capital he stayed there to help in the work of the Ottoman mission. Ahmet Muhtar Bey and Abdürreşid Ibrahim worked in Kiev under very difficult circumstances, in the midst of a bloody internal turmoil, to defend the rights of the Ottoman subjects there. ${ }^{44}$ Apart from the Ambassador, other Ottoman diplomats were appointed to consular missions in three Ukrainian cities. While Ahmet Ferid [Tek] Bey was sent to Kiev as Consul General on 15 July 1918, ${ }^{45}$ Eburriza Namık Bey was appointed Consul General in Odessa on 3 September $1918,{ }^{46}$ and Ruhi Bey Consul (second rank) in Kharkov on 12 August $1918 .{ }^{47}$

Nevertheless, the defeat of the Central Powers and the ensuing chaos in Ukraine did not allow the Ottoman diplomats to stay long. Apparently Ahmet Muhtar Bey could return to Istanbul no earlier than mid-February 1919, after some adventure on the way, ${ }^{48}$ while Ahmed Ferid Bey stayed in Kiev a little longer, though he arrived in Istanbul not much later than Ahmet Muhtar Bey. ${ }^{49}$ Ahmet Muhtar Bey's diplomatic assignment and the Ottoman mission to Ukraine was officially terminated on 1 April $1919 .{ }^{50}$

Despite the relative brevity of their missions in Ukraine the Ottoman diplomats contrived to acquire an insight into Ukrainian affairs. The circumstantial report of Ahmed Ferid Bey to Istanbul on 5 September 1918 is an example of this. There, he analysed the political, economic and demographic situation in Ukraine. He especially pointed out the organizational and administrative deficiencies of the young Ukrainian state and the conflicting orientations among its rulers. Ahmed Ferid Bey expressed his serious doubts that the Ukrainian state as it was could be viable at a time when its Prime Minister (Fedir Lyzohub) was strongly proRussian and made no secret of his desires for the formation of a Russian 
Federation, while Ministers of Foreign Affairs (Dmytro Doroshenko) and People's Education (Mykola Vasylenko) were fervent Ukrainian. nationalists. According to Ahmed Ferid Bey's observations, many people considered independence a political expedient to escape Bolshevik invasion. ${ }^{51}$

Apart from the diplomats there were some other Ottoman personages who visited Ukraine. Among such men were the famous journalist and writer Celâl Nuri [İleri]. Also, the reopening of the navigation line between Odessa and the Turkish Black Sea ports made a modicum of trade possible between the two countries. ${ }^{52}$ It is well known that sometime during the last days of the war, the Ukrainian government, through the Ottoman Consulate General in Kiev, offered to barter certain goods with Turkey. The Ukrainians asked for petroleum, gasoline, naphtha and machine oil, in return for wheat, barley, sugar and iron. Yet the post-armistice diplomatic and political proscriptions, as well as the current circumstances, discouraged the realization of any such economic exchange..$^{53}$

On the other hand, Levyts'kyi was called back by the newly formed Hetman's government in Kiev no later than early June $1918 .^{54}$ The resident Ukrainian diplomatic missions were to be established soon afterwards. Initially, in June 1918, the news appeared in the Ottoman press (via Vienna) that Petro Chykalenko would be the first resident envoy of Ukraine in Istanbul..$^{55}$ Chykalenko indeed came to Istanbul, but his title was chargé d'affaires; the ambassador was yet to be appointed. In August, for some unknown reason, an improbable rumour spread in the Istanbul press about the appointment of Khristian Rakovskii, the famous Bolshevik of Bulgarian origin who had headed the Bolshevik delegation to Kiev. This obviously annoyed Chykalenko who hurried to deny the rumour to the Ottoman Foreign Ministry on 26 August 1918. He also informed the Ottoman government that Bogdan [?] Kistyakovskii, brother of Igor A. Kistyakovskii, Minister of Interior Affairs, was appointed Ukrainian Ambassador to Istanbul. ${ }^{56}$ Kistyakovskii was supposed to travel to Istanbul on 12 October $1918 .{ }^{57}$ Yet, he resigned before he arrived to the Ottoman capital..$^{58}$

Finally, the Ukrainian government notified its Ottoman counterpart of the appointment of Mikhail Sukovkin with the title of extraordinary envoy and plenipotentiary minister. ${ }^{59}$ The Ottoman government declared its approval of Sukovkin's post as an extraordinary envoy on 9 November $1918 .^{60}$ Sukovkin left Kiev for Istanbul on 26 October 1918. ${ }^{61}$ The arrival of Sukovkin and his embassy in Istanbul coincided with the Ottoman withdrawal from the war. The defeated Ottoman government signed the Armistice of Mudros on 30 October 1918 and soon occupation forces of the Entente arrived in Istanbul. The new situation, of course, was to affect the Ottoman-Ukrainian relations immediately and radically. 
Sukovkin's personality and his activities in Istanbul proved to be most controversial. By origin, he was a Russian. He had worked in the Tsarist bureaucracy as a gubernator and before the 1917 revolution he had been the head of the Kievan provincial zemstvo. During the early days of the revolution Sukovkin declared himself an adherent of the Ukrainian state, whereupon the Central Rada nominated him Regional Commissar (Kraevoi Komissar) of Ukraine to the Russian Provisional Government. Even Myhaylo Hrushevs'kyi praised his devotion to Ukraine in a provincial zemstvo meeting. ${ }^{62}$ Oleksander Shul'hin, the prominent Ukrainian nationalist and the first Ukrainian Foreign Minister, later characterized him as among the Russians and Tsarist bureaucrats and plutocrats, such as Igor Kistyakovskii, Sergei Gerbel and others, who found a haven in Ukraine and offered their services. According to Shul'hin, these men 'having agreed with the indisposed and unprincipled Skoropads'kyi, thought of rebuilding old Russia on the neck of Ukraine. ${ }^{63}$ In his memoirs, Skoropads'kyi writes, 'I cannot say anything either good or bad about [Sukovkin], [his being sent to Turkey] was the choice of Minister Doroshenko. I do not know Sukovkin. ${ }^{54}$

In any case, Sukovkin's subsequent activities evinced that he had hardly reconciled himself to the idea of an independent Ukraine and he opted to act more in the interests of a future united (federated) Russia than in those of Ukraine. It is obvious that from the very beginning of his mission Sukovkin made it clear that he favoured the revival of a unified Russia. As a matter of fact, Hetman Skoropads'kyi's edict of 14 November 1918, which read, 'Ukraine must take the lead in the matter of establishment of an All-Russian federation, the final goal of which will be the restoration of Great Russia', ${ }^{\text {ss }}$ was certainly a blessing to Sukovkin. On 15 November 1918, when Sukovkin was not informed of the Hetman's edict yet, he told Ali Merdan Bey Topçubaşı, the Azerbaijani envoy who visited him on the Ukrainian consulate yacht Velikii Kniaz Aleksandr Mikhailovich, that Ukraine would not oppose a federal union of the states which had come into being with the disintegration of the Russian Empire. According to him, such a federation could be analogous to that of the United States of America, but a united [yedinoe] Russian state as it had been before, would be unthinkable. He also told Topçubaş1 that his mission was preparing a memorandum [zapiska] which was to illuminate the future position of Ukraine vis-à-vis Great Russia, Poland, and some other countries, and which was to be distributed to all diplomatic missions. ${ }^{66}$

As soon as Sukovkin learned about the Hetman's edict on 21 November 1918, he changed the official language of the Ukrainian mission from Ukrainian to Russian. He also took down the Ukrainian flag on the mast of the consulate yacht Velikii Kniaz Aleksandr Mikhailovich and hoisted the flag of St Andrew instead, as he made the crew shout 'hurrah' in celebration 
of the event. ${ }^{67}$ At the same time, probably in accordance with the directives of pro-Russian Georgii Afanas'yev, the Foreign Minister, he notified diplomatic circles and the Ottoman Foreign ministry that Ukraine considered itself part of Great Russia and would willingly be a terrain for the rebuilding of the latter. ${ }^{68}$ Sukovkin distributed copies of Skoropads'kyi's edict as well. When more information about its meaning was requested, he sent Prince Tenishev, his first secretary and a Russian, who used to be the dragoman of the Russian Embassy. ${ }^{69} \mathrm{He}$ replaced General $\mathrm{Dr}$ Kobylyans'kyi, the counsellor and Ukrainian nationalist, with Tuholka on the pretext of the former's Polish sympathies. The Russian monarchist émigré circles in Istanbul were Sukovkin's closest companions. He was in close touch with Countess Brasova, the sister-in-law of the last Tsar, Pavel Nikolaevich Miliukov, Sergei Dmitrievich Sazonov, Prince Dolgorukov, Gurko, and other prominent figures. ${ }^{70}$

Sukovkin was received by the Sultan Mehmed VI Vahdeddin on 28 November 1918 and submitted his credentials as the Ukrainian envoy." Notably, during the reception Sukovkin wore a Russian uniform. This was noticed by Mustafa Kemal Pasha (future Atatürk) who happened to be there. When questioned by Mustafa Kemal Pasha as to the reason why he wore a Russian uniform, Sukovkin gave the unconvincing answer that they had not had enough time to order a Ukrainian uniform before they left Kiev. ${ }^{72}$

The defeat of the Central Powers and rising discontent soon led to the downfall of the Hetman's regime. The nationalist and socialist opposition started an insurrection against the Hetman and a 'Directorate' was formed to claim power. The Directorate possessed armed forces and declared Skoropads'kyi a traitor. The Hetmanate collapsed almost the moment the remaining German forces decided to terminate their role as the protectors of Skoropads'kyi and to withdraw. Hetman's meagre military forces were thus reduced to a few Russian officers. The forces of the Directorate led by Colonel Evhen Konovalets entered Kiev on 14 December 1918. Skoropads'kyi fled the city donning a German uniform.

When the information about the insurrection against the Hetmanate and its eventual collapse reached Istanbul, Sukovkin's reaction was characteristic: he spread among the Turkish and foreign circles the false news that the insurrection had an ultra-nationalist and Bolshevik character, and called for the Entente forces to intervene to help the Hetmanate. ${ }^{73} \mathrm{He}$ also assured the foreign diplomats that no independence movement existed in Ukraine except for the Bolshevik intrigues and revolutionary chaos, and that everything that was civilized and cultured was indeed Russian. He sneered at Kobylyans'kyi whom he called the 'pompous Pole'. ${ }^{74}$ When he visited the Ecumenical Greek Orthodox Patriarch of Constantinople, he reiterated that the Russian people and state were one and indivisible. On the 
occasion of the Patriarch's visit of the Ukrainian Embassy, Sukovkin publicly stated the unity of the Russian and Ukrainian churches. ${ }^{75}$ In the meantime, Sukovkin continued the thorough Russification of the Ukrainian Embassy on which he set out after the edict of the Hetmanate. Whenever possible Sukovkin appeared decorated with Russian medals and in the company of officers attached to the embassy in Russian uniforms. ${ }^{76}$

In early January 1919, when the Ukrainian government recalled Sukovkin and ordered him to leave the administration of the embassy to Kobylyans'kyi, Sukovkin not only refused to abide by the order, but also gave a statement to the Ottoman government that the Ukrainian government and its representatives were 'Bolsheviks'. ${ }^{77}$ As a matter of fact, he had applied to the Ottoman Foreign Ministry with the request of a loan of 10,000 Turkish Liras. He failed to receive the money. Finally, he informed the Ottoman Foreign Ministry on 3 March 1919 that the Ukrainian Embassy had terminated its activities as of 1 March due to the lack of financial resources. ${ }^{78}$

On the other hand, the Ukrainian government had already appointed, in mid-January 1919, a new extraordinary envoy and plenipotentiary minister to replace Sukovkin. Oleksander Lotots'kyi would be the new Ukrainian envoy in Istanbul. ${ }^{79}$ Lotots'kyi was a well-known figure in Ukrainian political circles. A man with a sound clerical and theological education, before 1917 he held high positions in the Ministry of State for the Control of Finance. After the collapse of Tsarism, he had been appointed by the Russian Provisional Government as Governor of Bukovina, and later he had become the Chancellor of State in the first Ukrainian autonomous government in September 1917. In the spring of 1918 he had been appointed State Controller in the Ukrainian government, and had served as the Minister of Religious Cults in the Hetman's cabinet. Upon the latter's edict for a federation with Russia, he had resigned from his post, only to be offered the same post in the succeeding Directorate government. As one of the most renowned experts of canonical law in Ukraine, it was Lotots'kyi who had prepared the law which established the autocephaly of the Ukrainian Orthodox Church on 1 January 1919.80

In view of Lotots'kyi's career and experience, he was certainly not a fortuitous choice as envoy to Istanbul. On the one hand, a fervent patriot and dedicated defender of Ukrainian independence, he seemed to be the ideal person to repair the damage done to the prestige and dignity of the Ukrainian state by Sukovkin. On the other hand, the Directorate government considered the recognition of the Ukrainian Autocephalous Orthodox Church by the Ecumenical Patriarch of Constantinople vital. Ukrainian Orthodoxy used to be within the jurisdiction of the Constantinople Church until 1686, when, following the Russian annexation of Ukraine, it had 
shifted its allegiance to the Patriarch of Moscow. The change of ecclesiastical allegiance in late seventeenth century was a direct result of the altered political subordination. Now, an inevitable component of the political liberation from Russia would be the departure from the ecclesiastical jurisdiction of the Patriarchate of Moscow. The ecclesiastical legitimacy of the Ukrainian Autocephalous Church independent from the Moscow Church could be obtained only through its recognition by, and formal subordination to, the Ecumenical Church of Constantinople. To this effect, Volodimir Chehovs'kyi, the Prime Minister of the Directorate government, considered Lotots'kyi the right man with the necessary religious knowledge and experience, who was, after all, the very author of the autocephaly. ${ }^{81}$

As soon as the news of Lotots'kyi's appointment reached Istanbul, the senior deputy [starshiy zamestitel'] Kobylyans'kyi, took over the administration of the Ukrainian embassy. In order to fix the situation with the Ukrainian government Kobylyans'kyi dispatched one of their personnel to Odessa. Through him, Bachyns'kyi, the Ukrainian Deputy Foreign Minister, sent his instructions to the effect that Sukovkin surrender all the mission's work to Kobylyans'kyi, who was to be in charge of the affairs of the embassy until Lotots'kyi's arrival. Thus, after a month's interval, the Ukrainian mission in Istanbul began to function again under Kobylyans'kyi. $\mathrm{He}$ informed Ferid Pasha, the Ottoman Foreign Minister, about the resumption of the functioning of the mission. ${ }^{82}$ The Ottoman press, which was also notified about the situation, heralded the reopening of the embassy in the second half of April 1919.83 Yet, the embassy's activities recommenced in theory rather than in practice. Sukovkin not only refused to resign from his post until his salary was paid, but also sent angry letters to the Ottoman Foreign Ministry and the diplomatic missions in Istanbul in which he remonstrated against the reopening of the embassy. ${ }^{84}$

The troubles created by Sukovkin did not come to an end after the arrival of Lotots'kyi in Istanbul via Vienna, Trieste and Venice on 23 April $1919 .{ }^{85}$ While he was travelling through Vienna he met Yan (Ivan) Tokarzhevs'kyiKarashevych, the counsellor of the Ukrainian mission there, and took the latter with him to Istanbul. ${ }^{86}$ As soon as he had taken office, Lotots'kyi met Sukovkin and handed him the order of the Directorate. The latter reluctantly gave Lotots'kyi some of the embassy's possessions, though these did not include the commodity inventory and certain important documents and notebooks. When Sukovkin demanded money for his pains, Lotots'kyi asked him to wait until June for the settlement of embassy's financial matters and accounts. Such an inspection of the accounts was to perplex Lotots'kyi. As Lotots'kyi later narrated in his memoirs, Sukovkin had sold several valuable articles from the inventory, including an automobile, 
credits had been taken from the banks, large sums of indemnities had been paid to the dismissed workers, and the exchange rate of Karbovanets for the Ottoman Lira had been arbitrarily fixed. The overall financial situation of the mission left little place for optimism, and, without finding suitable credits, it would be impossible to run the legation. On the other hand, Sukovkin proved to be very tenacious in demanding his claims immediately. As the embassy was not in a position to pay him straightaway, he appealed again to the Ottoman government and requested that Lotots'kyi not be recognized as the Ukrainian envoy. Sukovkin's open struggle with the Ukrainian mission and his vilifications were not ineffective. After all, he had very close relations with [White] Russian circles (there were even rumours that he wanted to become the representative of the Voluntary Army of General Anton Ivanovich Denikin), who were the masters of the day in Istanbul, and especially with the victorious Entente powers, who put Istanbul under their military occupation and enjoyed a great deal of influence over the affairs of the vanguished Ottoman Empire. Under these circumstances the official recognition of Lotots'kyi by the Ottoman government became all the more complicated. When he considered making a démarche to protest at the Ottoman reluctance to recognize him, his Turkish friends asked him to refrain from such an act and told him that the change of the Ottoman government would solve the problem. ${ }^{87}$

The heart of the matter was of course far beyond the individual attitude and policy of this or the other Ottoman government. Under the Entente occupation the weak governments of the Sultan had little space for unconstrained action independent of the will of the occupants. For the Entente Powers, who publicly cast their lot with the anti-Bolshevik 'White' armies, the principle of a 'united and indivisible Russia' was paramount. Therefore, the concept of an independent Ukraine breakway from Russia, even one fervently and uncompromisingly antagonistic to the Bolsheviks, was not acceptable to the Entente. Hardly any of the post-Mudros Ottoman governments, all of which were built on most delicate political balances, could sturdily confront the seemingly all-powerful Entente on the issue of Ukraine which was obviously not a priority on the overfull Turkish agenda. Otherwise the Ottoman public and political circles were, as before, very sympathetic to the idea of an independent Ukraine.

Thus, from the outset, the persistent efforts of Lotots'kyi to obtain an audience with the Sultan and formal recognition on the part of the Ottoman government were doomed to failure. Though not a factor critical to Ottoman diplomatic decision-making mechanism, Sukovkin's dogged efforts at defamation might have created at least some quandary on the part of the Ottoman diplomats who were in a position to deal with Ukrainian matters. Although Lotots'kyi possessed the lettres de créance of his government, the 
Directorate had not given a lettre de rappel for Sukovkin, considering that in case of a change of government the representatives abroad should leave office unless provided with a written instruction of the new government. This lack of lettres de rappel for Sukovkin was exploited by the latter against Lotots'kyi. To clarify the situation before the Ottoman government, the Foreign Ministry of the Directorate sent a letter of explanation to the Grand Vizier on 13 May $1919 .{ }^{88}$

The failure to achieve formal recognition did not thwart Lotots'kyi in establishing good and cordial relations with Ottoman political and diplomatic circles. For instance, Safa Bey, the Ottoman Foreign Minister, displayed a great deal of formal and personal respect to Lotots'kyi to whom on one occasion he paid a home visit. It was such Ottoman diplomats and officials who frankly confessed to Lotots'kyi that their inability to recognize him and arrange an audience with the Sultan was due to their worries of recognizing a state not recognized by the Entente. ${ }^{89}$ This being the case however, it is notable that the Ottomans did not object to the presence of the Ukrainian mission in Istanbul and preferred to accept it tacitly as an uninterrupted perpetuation of the purely legitimate Ottoman-Ukrainian relations since Brest-Litovsk.

Formally recognized or not as a de facto representative of Ukraine in Istanbul at a most turbulent time for both countries, Lotots'kyi had a manifold set of issues to deal with. At times when most of the territory claimed by the Ukrainian goverment (i.e. the Directorate) was trodden by different parties of warring Russians and other foreigners and the very government itself was for the most part reduced to a peripatetic body with limited power, the continuing presence of a diplomatic legation in Istanbul would testify to the existence of Ukraine as an independent political entity. Therefore, it was imperative to maintain the embassy in the Ottoman capital. Apart from this, there were a number of questions with which such a mission had to deal: the recogniton of the Ukrainian Autocephalous Church by the Patriarchate of Constantinople, the establishment of trade relations between Turkey and Ukraine, the reclamation of certain sea vessels and properties which were then in the hands of the 'White' Russians or the Entente Powers, ordinary consulate services for the several thousands of Ukrainian citizens who had flocked to Istanbul due to the war and disorder at home, providing an outlet to the outside world for the cornered Ukrainian government and offering support for it, including military support, etc.

Not much discouraged by the obvious want of the necessary resources to cope with such complicated tasks, Lotots'kyi set about a thorough reorganization of the embassy. He had little knowledge of the embassy personnel and their disposition toward Sukovkin. Consequently, he retained 
some of the staff, while he fired others. ${ }^{90}$ There were also some functionaries, such as Tokarzhevs'kyi-Karashevych, whom Lotots'kyi brought with him. As far as the work of the mission was concerned, it was virtually in a very disorderly state. There was no longer a place for the embassy and the official address of the legation was presented as the private home of one of the staff. The papers of the embassy were either lost (or had been taken by Sukovkin) or disordered. Only the accounts book and related documents had been kept by the accountant. The staff had not been paid for some time and had to subsist under very difficult circumstances. Lotots'kyi first rented a building for the legation and commenced its work starting with issuing passports and visas. As there were some 40,000 people in Istanbul who had escaped from Odessa and other Ukrainian cities, this was a very urgent matter. ${ }^{91}$

The fate of what was left of the former Russian Imperial Black Sea Fleet had been a long-discussed problem since early 1918 after the collapse of the Tsarist (and soon Bolshevik) Russian power on the Black Sea. The Ukrainian flag had been hoisted on some of the ships which happened to be at the ports under Ukrainian control. The claims of the Ukrainian state were not confined to such military ships formerly belonging to the Black Sea Fleet and extended to those former Russian private merchant vessels which were registered to the ports which later became part of the Ukrainian state. In the aftermath of the First World War some of these vessels were in Istanbul. They were deemed necessary by the Entente Powers who wanted to use them in their assistance to the Russian Volunteer Army. On 26 November 1918 the pro-Russian envoy Sukovkin had agreed certain terms with Vice-Admiral Amet, the High Commissioner of France in Istanbul, about these vessels. According to this agreement, the ships in the Ukrainian ports which the French naval authorities would see fit, the yacht Aleksandr Mikhailovich anchored at Istanbul, and the steamers Koroleva Ol'ga, Tigr, and Ierusalim, and all steamers of the Ukrainian Navigation Union, were placed at the disposal of the Entente Powers to be used in the operations in Ukraine. ${ }^{92}$ Although in this agreement the French quite explicitly recognized that the vessels in question originally belonged to the Ukrainian state (whose de facto existence they thus avowed), the ships were for all practical purposes appropriated by the Entente Powers and, through them, by the Russian Volunteer Army, the irreconcilable foe of the very idea of Ukrainian statehood. Resenting the Sukovkin-Amet deal, Lotots'kyi did his best to reclaim the vessels and to prevent their takeover by Kolchak or Denikin. He was content with their sailing under Entente colours, so long as they transported supplies, goods, arms and troops for the benefit of Ukraine. Yet, to the great dismay of Lotots'kyi, many of these vessels had already been turned to the newly established Russian naval base in Istanbul which was 
under the command of Kolchak's forces. Lotots'kyi repeatedly appealed to the French High Commission in Istanbul in August and September 1919, but these appeals fell on deaf ears. ${ }^{93}$ Having learned about the appeal of the Dutch legation in Istanbul which simultaneously represented Russian interests at the Ottoman capital requesting the return of Koroleva Ol'ga to its Russian 'owners', Lotots'kyi wrote to the Ottoman Foreign Ministry to prevent such a transfer and demanded its transfer to its real owners under Ukrainian colours. ${ }^{94}$ All such efforts of the Ukrainian mission proved to be in vain. Not even replies were sent to Lotots'kyi or Tokarzhevs'kyiKarashevych, his successor.

Connected with the prospects of acquiring control over those vessels was the transportation of the would-be Ukrainian soldiers to be recruited from among the prisoners of war. In 1919, there were many ethnic Ukrainian prisoners of war of various origins. A group of them were Galicians and Bukovinians, members of the former Austro-Hungarian army who had been captured on the Western Front. They were held by the French and used by them in a number of duties for the Entente. On 3 July 1919 Lotots'kyi appealed to the French with a memorandum and asked to recruit them into the Ukrainian army which was then fighting the Bolsheviks. He proposed the organization of these prisoners of war into a detachment, supplying them with clothing and ammunition, and their shipment to Southern Ukraine by French vessels. Lotots'kyi could get only a private and verbal reply to the effect that the local military command would look for a solution with the central command. He also appealed to the Romanian embassy on behalf of the Bukovinians to allow their return to their homes. This time he was somewhat more successful and these Bukovinians were indeed sent home. The Galicians were to be shipped much later. ${ }^{95}$ In fact, there were different sorts of 'Ukrainian' prisoners of war. In addition to the above-mentioned Galicians and Bukovinians who used to be the subjects of the ex-Habsburg Empire, there were much more numerous 'Russian Ukrainians' who had been captured by the Central Powers as soldiers of the Russian imperial army. To be sure, it was by no means a simple business to determine who could be properly qualified as a 'Ukrainian' as distinct from a 'Russian', since there had been no official documents to indicate their ethnic or national origins at the time of their capture. In 1919 there were some 90,000 prisoners of war of the former Russian (Tsarist) army who were travelling homeward from Germany via France and were taken to Marseille for embarkation. The Ukrainian mission in Istanbul estimated that at least one-third of these men should be counted as Ukrainians and appealed to the French for their safe handover to the Ukrainian authorities. Lotots'kyi also appealed to the British authorities in Istanbul about the Ukrainian ex-prisoners of war, who were then in British hands, though apparently to no avail. ${ }^{96}$ 
The issue of the return of the ex-prisoners of war was a very pressing concern for Lotots'kyi. Not only did the Ukrainian state (Directorate) desperately need fighters (and particularly those provided by others), but any disembarkation of such ex-prisoners of war to the wrong places carried the dire risk of delivering these men into the hands of the Bolsheviks and thus furnishing the enemy with fresh recruits. Precisely this had taken place in spring 1919 when the Entente navy disembarked some 1,300 such former soldiers of the Tsarist army to Odessa and Ochakov, then under Bolshevik occupation. In his note to the Entente representatives on 8 August 1919, an exasperated Lotots'kyi protested at the event and asked for the adoption of the necessary measures so that it would not be repeated. What had added insult to the injury for the Ukrainian legation was that the transportation of the above-mentioned ex-prisoners of war had taken place on the very ships which had been left to the use of the Entente by the Sukovkin-Amet deal supposedly to provide support for Ukraine. ${ }^{97}$ Lotots'kyi also applied to the Ottoman government on 10 August 1919 to receive permission to recruit those Galicians who had been captured by the Entente while serving in the Austro-Hungarian army and who were then detained at the French headquarters. The Ottoman Foreign Ministry was of the opinion that a foreign mission in the Ottoman Empire had the legitimate right to call up its subjects, but it was inadmissible to exert force to summon them and to form any military unit on Ottoman territory. After all, these men were at that time held by the Entente forces which were practically beyond the jurisdiction of the Ottoman government. In consideration of all the complications and delicacies involved, the Ottoman Foreign Ministry decided not to give any reply to the Ukrainian request. ${ }^{98}$

Another issue which preoccupied Ukrainian legation in Istanbul was the printing and circulation of Ukrainian banknotes [karbovantsy] and bonds unauthorized by the Ukrainian government. Such an incident had taken place in Odessa as the Ukrainian Papermoney Emission Bureau continued to operate when the city was under the Entente occupation between November 1918 and April 1919. A telegram of the Finance Minister of Russian (Denikin's) government in Rostov indicated that these banknotes had been printed by them. The Ukrainian Directorate did not know the actual amount of these unauthorized banknotes and securities. In his memoranda to the French and British High Commissioners in Istanbul, on 23 and 25 September 1919 respectively, Lotots'kyi protested against the incident, asked the value of the karbovantsy printed without authorization and the names of those responsible, and declared that his government would not accept these notes as valid, as stated in the ordinance of the Ukrainian Finance Ministry on 27 July $1919.9^{99}$ Like his other appeals and protests, Lotots'kyi received no response from the Entente Powers. 
Certainly, one of the priorities in the mission of Lotots'kyi was to obtain the official recognition of the Ecumenical Patriarchate of Constantinople (Fener) for the Ukrainian Autocephalous Church. At the time of Lotots'kyi presence in Istanbul, the seat of the Patriarch was vacant and the patriarchal election had been postponed until a definite peace settlement was concluded. The Metropolitan of Bursa, Dorotheos Mammelis had been elected by Fener the acting Patriarch [locum tenens]. ${ }^{100}$ When Lotots'kyi visited the Patriarchate at Fener in July, he was received very warmly by the acting Patriarch and the prelates. Dorotheos returned this visit only the next day at the residence of Lotots'kyi in Tarabya, a suburb of Istanbul. Lotots'kyi and Dorotheos met each other over the following months on religious and personal occasions. On every occasion Lotots'kyi explained his cause to Dorotheos and other dignitaries of Fener. The Ukrainian legation also published and distributed a pamphlet in Greek about 'the historical link of the Ukrainian Church with its mother Church of Constantinople' to win over Fener. ${ }^{101}$

The warm personal and formal relations notwithstanding, the acting Patriarch was in no hurry to accept Lotots'kyi's solicitation for the Ukrainian Autocephalous Church and backed out of the issue at the moment. If nothing else, there was the fact that Lotots'kyi was not the only person in Istanbul who brought the issue before the Ecumenical Patriarchate. Among the tens of thousands of 'White' refugees in Istanbul were several high-ranking Russian and pro-Moscow Ukrainian clergymen. They were actively and effectively lobbying against the recognition of the autocephaly of the Ukrainian Church. The Patriarchate could not simply ignore them. Moreover, there was not much reason for Fener to be convinced that the fall and disintegration of the Russian Empire were irreversible. After all, the military situation during the first half of 1919 was anything but promising for the future of an independent Ukraine. One should also not overlook the extremely full agenda of Fener in 1919. These were the times when under the dynamic and strongly nationalistic Dorotheos, Fener had committed himself more openly than ever to politics and exerted great efforts to bring about a diplomatic solution to the fate of Istanbul in favour of the Greeks, if possible the annexation of the city to Greece or at least the 'internationalization' of it with advantageous rights to its Greek population, in any case its separation from the Turkish rule for good. To bring about the desired outcome, Dorotheos was constantly busy lobbying the Entente authorities in Istanbul, sending delegations to Europe to influence the peace negotiations, and dealing with organizational activities among the Greek population of Istanbul. ${ }^{102}$ Therefore, Dorotheos could not commit himself wholeheartedly to the case of the Ukrainian Autocephalous Church which certainly had no priority for Fener, and was 
not really worth risking other relations and connections with the Entente at such difficult times.

These concerns of Fener were implied in the letter of reply to the Ukrainian government, whose draft was obtained by Lotots'kyi beforehand. There, having expressed the blessings of the Constantinople Church toward the Ukrainian people and the respect for its desire to turn its church into an autocephalous one, the Patriarchate specified three prerequisites for it: independence, the consent of the previously superior Church (i.e. Moscow), and the presence in office of the Ecumenical Patriarch on his seat to make this important decision legitimate. The acting Patriarch recommended the Ukrainians to wait for the election of the new Patriarch so that their request could be answered firmly in the affirmative. These conditions, and especially the first one which questioned the independence of Ukraine caused a great deal of indignation among the Ukrainian mission who sharply protested to the author(s) of the letter. The requirement for the consent of the Moscovite Church, which was the least likely prospect, could only be an expedient on the part of Fener to drag out the issue indefinitely. Moreover, the prevailing vacancy of the seat of the Patriarch had certainly given the acting Patriarch a suitable pretext to avoid offering Lotots'kyi a positive answer. Thus, the contents of the draft letter which were prevented from being sent caused some chill in the relations between the Ukrainian legation and Fener. Subsequently, however, the cordial atmosphere between Lotots'kyi and Dorotheos was restored. Just before Lotots'kyi left Istanbul, an amended letter of reply to the Ukrainian government was penned by Fener. In this letter, dated 9 March 1920, Dorotheos did not make any mention of the previous prerequisites of independence and consent of Moscow, but politely stated that Fener could not confirm the authocephaly of the Ukrainian Church at the moment because of the current vacancy in the Patriarchal see. ${ }^{103}$

The failure to obtain the formal support and sanction of the Ecumenical Church was of course a substantial frustration, if not an intense embitterment, for the Ukrainian mission, particularly for Lotots'kyi who had cherished deep hopes about it. This being the case however, the Ukrainian legation in Istanbul was beset by several complications of much urgent nature which overshadowed its disappointment with Fener. No doubt, the foremost concerns of the legation were the great uncertainties about the future (and of course, the current) situation of Ukraine and its independent government whom Lotots'kyi and his handful of subordinates were supposed to represent and from whom a healthy way of receiving timely information could not be found. What described itself as the Ukrainian government and the armed forces under its command were in the midst of an ongoing struggle against the Bolsheviks, Makhnovites, Whites, 
and multifarious local bands consisting of simple brigands rather than ideological or political groups, and the sides and alliances in this struggle were subject to sharp changes all the time. Throughout the largest part of 1919 and 1920, the Directorate or the Ukrainian government could hold only on a narrow strip of land in the westernmost part of what it claimed as the territory of Ukraine or it was deprived of even that much as it would be compelled to operate on foreign territory. Certain military achievements which were crowned with the extension of the area controlled by the Directorate to large parts of the country including the capital Kiev, proved to be temporary and rather results of the ebbs and flows of the struggle between the Bolshevik and non-Bolshevik ('White') Russian armies or the Polish army. In brief, as the very state and government which the legation in Istanbul claimed to represent for the most part enjoyed but a nominal existence. This conjuncture, in addition to the fact that the concept of an independent Ukraine (or Ukraine at all) was still a novel one and had been recognized by only a few countries most of whom had to revoke their decisions as a result of their defeat in the war, made the position and status of the Ukrainian mission in Istanbul quite awkward.

The prevailing political situation in Istanbul was no less auspicuous. Istanbul was under the occupation of the victorious Entente Powers who did not hesitate to impose their will on the powerless Ottoman governments and the city overflowed with tens of thousands of 'White' Russian refugees. The latter included numerous political and military figures who were champions of the idea of 'Mother Russia - One and Indivisible' and did not harbour the least sympathy or tolerance for a separate Ukrainian identity, let alone independence. The 'White' Russian movement was, by and large, supported and sponsored by the Entente, who shared the attitude of the former vis- $\grave{a}-$ $v i s$ the indivisibility of Russia. Ukrainian independence was never endorsed by Britain or France who, apart from the idea of preserving the territorial integrity of the Russian empire as intact as possible, viewed the Ukrainian Democratic Republic a creation and satellite of Germany. This is not to say that Britain and France had a really concerted policy on matters concerning Russia. They had sharp differences at different times in their approach toward this or the other Russian group. Not even their support of the 'White' armies were unshakable. Still, whether Britain supported one 'White' group and France backed another, or, having exhausted all realistic hopes about the restoration of the old order in Russia, they considered a sort of reconciliation with the Bolsheviks, none of these policies allowed a place for an independent Ukraine. On that account, it would be vain to expect any formal recognition on the part of the Entente Powers of the independence of Ukraine. Yet, as a political and military entity of certain significant power irreconcilably antagonistic to the Bolsheviks, the Ukrainian government had 
not been totally ignored by Britain and France, who had their unofficial representatives in Ukraine. ${ }^{104}$ After all, no matter what its clauses were, the Amet-Sukovkin agreement was in a sense a de facto recognition of Ukraine. In any case, the Entente authorities, not to mention the 'White' Russian dignitaries in Istanbul, displayed no intention to co-operate with the Ukrainian legation whose presence there was deemed a nuisance at best.

Thus, the Ukrainian legation had to conduct its duties under severe pressures and harassment. Russian circles in Istanbul, especially that of General Agapiev, the representative of Denikin, effectively propagandized against the presence of a Ukrainian mission. They accused the Ukrainian diplomats of collaborating with the Bolsheviks, Germans, and the nationalist forces of Mustafa Kemal Pasha in Anatolia, as well as of forgery. ${ }^{105}$ The Ukrainians were also anxious about their physical safety in the presence of so many intimidating elements. Denikin's intelligence service in Istanbul was constantly watching the activities of the legation and often sent its agents to provide information from within. There were certainly several double agents. ${ }^{106}$

The defamation activities against the Ukrainian legation did not remain ineffective and the Entente authorities initiated police measures against it. First, on 9 September 1919, the Counsellor Kobylyans'kyi and the attaché Rathhaus were subjected to a thorough search by the Interallied police and the sealed baggage of the legation was taken to the British Headquarters. ${ }^{107}$ This incident was followed by a more wholesale assault. On 25 September 1919 the Entente police under the command of the British LieutenantColonel Maxwell, together with some Russian civilians, organized a raid on the Ukrainian mission. In reply to protests by Lotots'kyi, Maxwell explained that he acted in accordance with the orders of the British High Commission. They not only minutely searched the mission's office and the private apartments of the envoy and the counsellor, but also temporarily detained the diplomats and functionaries there. Besides the diplomatic and political documents, bank cheques and several private papers were confiscated. The office was sealed off and guards were installed in front of its entrance. Moreover, the bank accounts of the mission at Crédit Lyonnais were frozen. Lotots'kyi subsequently sent notes of protest to the Entente High Commissioners, the Ottoman Foreign Ministry and the diplomatic missions of the neutral states and demanded the return of the confiscated materials, but to no avail. ${ }^{108}$ Having been deprived of their income and even their premises, the members of the legation fell into a very difficult financial situation. Lotots'kyi rented a suite at the famous Hotel Pera Palace and began to conduct his meetings there (Soon, however, he had to move due to the overwhelming expenses). A representative of the Ottoman Foreign Ministry visited him at the hotel and explained the regrets of his government 
about what had taken place and that they were not in a state to extend much support to the Ukrainian mission. So did a representative of the Patriarchate of Constantinople. As the result of the investigations undertaken by the Entente authorities refuted the claims about the Bolshevik connections of 'the persons describing themselves as members of the 'Ukraine Legation', the office of the legation was allowed to be reopened a month later. ${ }^{109}$

All these unfavourable circumstances notwithstanding, the Ukrainian mission tried to continue its work. The inimical attitude of the British and French High Commissions as well as that of the Russian groups could not be changed, but Lotots'kyi and his functionaries did their best to maintain good relations at least with the other diplomatic missions in Istanbul. Good and businesslike relations were established with the representatives of the United States and Romania despite the fact that they too belonged to the Entente, though they did not actively participate in its military operations in Turkey. This was the case too with the diplomatic missions of Sweden, Iran and the newly independent Azerbaijan and Georgia. The fruits of good relations with these foreign representatives and officials were taken when the office of the Ukrainian legation was shut down, as they openly displayed their sympathies with the Ukrainians. ${ }^{110}$

The Ukrainian legation endeavoured to reach out to the European and Ottoman government and public with its own version of the Ukrainian events by issuing many memoranda, notes and declarations. It also worked on publishing a number of pamphlets and leaflets in different languages. One such pamphlet was the above-mentioned one penned in Greek addressing the Patriarchate. Another one was written by Lotots'kyi and published in Turkish, with the title 'Turkey and Ukraine' [Türkiye ve Ukrayna]. Lotots'kyi prepared two other pamphlets in French, one entitled L'Ukraine indépendante and explained facts about the independent state structure of Ukraine, and the other provided larger information about the same subject and also about the Ukrainian diplomatic missions abroad. Though the first two pamhlets were distributed, those in French were banned by the Entente censorship prior to their distribution. Tokarzhevs'kyi-Karashevych intended to write a long article surveying the past and present of the Ukrainian-Turkish relations in French, but due to the unfavourable circumstances of publication, he could not even complete writing it."1"

Much more important than these publications were certainly the efforts of Lotots'kyi and his subordinates, most of all Tokarzhevs'kyiKarashevych, to provide information for the press. This was especially significant since the outside world learned about the events on the territory of the former Russian Empire mostly through sources based in Istanbul, such as the 'White' Russian news agency Rusagen and Osvag. The 
Ukrainian legation, whenever the overall politico-military circumstances allowed, received interesting and detailed information from Ukraine, although at times a regular flow of such information proved impossible. Thus, Lotots'kyi and Tokarzhevs'kyi-Karashevych managed to establish good ties with certain Ottoman press circles and news items, commentaries, and interviews about Ukraine and Ukrainians appeared in the Ottoman press occasionally. The Turkish paper which displayed most affection toward the Ukraine was Iffham (Istanbul), with whose editor Hüseyin Ragip and Lotots'kyi had become good friends. In this task of illuminating the Ottoman public, Oksana Lotots'ka, daughter of the envoy (and future wife of Tokarzhevs'kyi-Karashevych), played an active role and established warm relations with Turkish women (Ifham published an interesting interview with her). As in all other matters, the obstructions of the proRussian Entente greatly hindered the publication of articles sympathetic to Ukraine in the press and in some cases even any sentences with the word 'Ukraine' would be deleted by the censorship. ${ }^{112}$

A long interview with Lotots'kyi in Ifham is a good example of his good connections with the Ottoman press. The interview was made at a time when the armed forces of the Directorate initiated a successful offensive against the Bolsheviks and began to recover many parts of the country. Therefore, the spirits of Lotots'kyi and his functionaries were raised. In the interview, having stressed the historical ties of the Ukrainians and Turks and especially their past alliances against the common enemy, i.e. the Russians, Lotots'kyi dwelled on the possibilities of mutually beneficial economic relations. According to him, the two countries indeed produced many commodities which the other needed. For example, Turkey could export lead, asphalt, nickel, sulphur, lime, marble, leather, silk, tobacco, fruits, and cotton, while Ukraine could provide Turkey with especially wheat and sugar, among many other things. He stated that Ukraine was a barrier for Turkey and other smaller states against Russia which would have been able to dominate them if it was not for this barrier. Commenting on Kolchak's refusal to recognize the independence of the breakaway republics until the convocation of the Russian National Assembly, Lotots'kyi said, 'The right to judge and decide upon the fate of Ukraine belongs to the Ukrainians and not to Kolchak. So long as they fight against the Russian Bolsheviks, Denikin and Kolchak can be considered as allies, since we are also fighting against the Soviets. Therefore we wish the success of Denikin and Kolchak. If necessary, we can even help the Volunteer Russian Army to enter Moscow. But if he (Denikin) gives up taking Moscow and marches against Ukraine and refuses to recognize the independence of Ukraine, it is a very different case. So it happened in the past. In 1918, Denikin wanted to subjugate Ukraine and the people rose and forced him out of the border. ${ }^{113}$ 
Indeed, Ifham continued its support for the Ukrainian cause. Upon the controversial information about the capture of Kiev by Petliura's forces or by the Russian Volunteer Army, Ifham urged its readers to think about the future of this country more seriously as it was a matter of the security of Anatolia. It was preferable to see a small Ukraine in the north of Anatolia, in lieu of a Great Russia. ${ }^{114}$

Apparently, Hüseyin Ragıp, the editor of Iffham, who was an active member of the nationalist Turkic Hearth Society (Türk Ocakları) also helped Lotots'kyi to get acquainted with Turkish political and intellectual circles. Interestingly, the former Ottoman ambassador Ahmed Muhtar Bey, the exConsul General to Kiev, Ahmed Ferid Bey (then, the Minister of State), Müfide Ferid Hanım, the latter's wife and a well-known figure of the Turkish women's movement, were among the close associates of Lotots'kyi in Istanbul. These respectable figures were harbouring sympathies for the emerging nationalist movement in Anatolia (in fact, they were to take part in and serve the Ankara government in the near future). Thus, Lotots'kyi was able to get regular information about the developments in Anatolia. Through these friends Lotots'kyi established good relations with notables and members of the Ottoman high society, such as Abdülhak Hâmid, the 'Great Master' of Turkish poetry, Ziya Pasha, İzzet Pasha, Ragıp Raif Bey, as well as certain influential members of the local Greek and Armenian community, such as, Peter Mavrokordatos, the Dadyan family, Iosip Azaryan, and others. Lotots'kyi's connection with influential circles in the Ottoman Empire was evident in the admission of his son, Boris, with a special governmental permission to the prestigious Imperial Lycée (Mekteb-î Sultanî) of Galatasaray which was exclusively for the Ottoman subjects. ${ }^{115}$

In the meantime, the military and political accomplishments of the Directorate government back in Ukraine proved ephemeral and the Ukrainian government was forced to retreat to a constantly-diminishing enclave in the westernmost part of the country and to conduct the last efforts of an already lost war. The deteriorating situation in Ukraine naturally affected the functions of the mission in Istanbul which was engulfed in an ever-deepening financial crisis. The number of the functionaries in the legation was steadily decreasing due to their being sent back home since April 1919, and by the autumn of that year only four people remained: the envoy, Counsellor, secretary, and interpreter. ${ }^{116}$ Lotots'kyi still firmly believed in the need for the presence of a Ukrainian legation in Istanbul, but the situation was becoming hopeless. Not much could be expected from an unrecognized and penniless legation of a waning state to an impotent government of a country under hostile foreign occupation. Under these circumstances, Lotots'kyi decided to leave Istanbul and hand the business of the mission to the Counsellor Tokarzhevs'kyi-Karashevych who was 
given the diplomatic title of minister plenipotentiary. Lotots'kyi preferred to tell the Ottoman government that his leave was temporary. He departed on 25 March 1920 and after a long journey arrived in Kamenetsk, the last stronghold of the Ukrainian government which accepted his resignation on 5 May $1920 .^{117}$

After the departure of Lotots'kyi and his daughter Oksana, who used to work as an interpreter, the Ukrainian legation was confined to only two men: Yan Tokarzhevs'kyi-Karashevych and V.P. Prykhod'ko, the secretary. ${ }^{118}$ Among the matters which Tokarzhevs'kyi-Karashevych inherited from his predecessor was the Ukrainian request to open consulates in Anatolia and Palestine, namely in Trabzon, Izmir, Adana, Damascus, Beirut, and Jerusalem. This was all the more strange since, with the exception of Trabzon, these cities were under foreign military occupation. Jerusalem, Beirut, and Damascus in which the Ottoman Empire retained all but purely nominal rights of sovereignty until the signing of the peace treaty, had fallen to the British in the course of war in 1917-18, following the Armistice of Mudros Adana and Izmir had been occupied by the French and Greek armies respectively. The stated purpose of these consulates would be to deal with the affairs of a large number of Ukrainians who would be found among the ex-Russian subjects in these regions, while the representatives of Denikin and Kolchak governments had already opened an office headed by a consul in Izmir. The Ukrainian legation had appealed to the Ottoman Foreign Ministry with these requests on 1 February $1920 .^{119}$ Apparently, Tokarzhevs'kyi-Karashevych met with Ahmed Reşid Bey, the director of the Political Section in the Ottoman Foreign Ministry during the first half of March 1920. The Ottoman official told Tokarzhevs'kyiKarashevych that the opening of any consulates in Jerusalem, Beirut, Adana, and Damascus was impossible due to the prevailing military occupations of the Entente there, though provisional functionaries could be sent to Izmir and Trabzon with letters from the Ottoman Foreign Ministry so that they would be treated as representatives of Ukraine by the local authorities. ${ }^{120}$ Nonetheless, the Ottoman Foreign Ministry had other concerns as well in rejecting such a request. The Ottoman diplomats had noticed that, unlike Germany and Austria which had been compelled to renounce their Brest-Litovsk Treaties by the Treaties of Versailles and Saint Germain respectively, no conclusive peace treaty was signed with the Ottoman government yet. Moreover, the clauses of the Armistice of Mudros did not contain any reference to the Treaty of Brest-Litovsk. Therefore, the Treaty of Brest-Litovsk was still legally in force between Ukraine and the Ottoman Empire. This being the case, however, any attempt, such as giving permission to open consulates, which would inevitably refer to the Treaty of Brest-Litovsk might remind the Entente Powers of the matter and induce 
them to exert pressure on the Ottoman Empire to nullify the Treaty. Thus, the Ottoman Foreign Ministry, desiring to let sleeping dogs lie, deemed it wiser to circumvent the issue and avoid giving an affirmative reply to the Ukrainians on the formal pretext of the unnatural state of affairs prevailing both in Ukraine and Turkey and the necessity of waiting for the signing of the peace treaties with the Entente Powers. ${ }^{121}$

In contrast with the period of Lotots'kyi who subsequently wrote and published his memoirs of diplomatic service in Istanbul in detail, we have relatively meager information about the mission of Tokarzhevs'kyiKarashevych in the Ottoman capital which at any rate lasted more than a year-and-a-half. The latter's mission must have functioned under even more difficult and complicated circumstances than his predecessor. This, if not for anything else, was due to the fact that the independent Ukrainian state practically ceased to exist on the territory it claimed and the power of the Sultan's government which tried to operate under the Entente military occupation hardly went beyond Istanbul, if there at all, and was more and more outshoneby the nationalist government of Ankara. Even under this state of affairs, however, evidence suggests that Ottoman diplomacy did not lose its interest in the independence of Ukraine. The Treaty of Sèvres, which the Ottoman government was compelled to sign on 10 August 1920, explicitly imposed the nullification of the Treaty of Brest-Litovsk. Thereby, of course, the Ottoman recognition of the Ukrainian independence and its official relations with Ukraine would be rendered null and void. Yet the Ottoman Foreign Ministry clearly did not want to revoke its official recognition of Ukrainian independence and looked for a licit way to do so. This attitude was clearly perceptible in its reaction to the request of the Ukrainian Foreign Ministry (then in exile) about the confirmation of Tokarzhevs'kyi-Karashevych as the minister plenipotentiary of Ukraine in Turkey on 30 November 1920. The legal office of the Ottoman Foreign Ministry thought that it would be totally legitimate to confirm the change of a diplomat of a recognized foreign country. The nullification of such a recognition by the Treaty of Sèvres was not effective yet, since that Treaty could be officially in force only after its ratification in Paris. Therefore, even now the legal office recommended to abide by the system of Brest-Litovsk. Nevertheless, a protocol for consulates between the Ottoman Empire and Ukraine was still lacking at the moment and this absence would hamper the recognition of the Ukrainian minister plenipotentiary. Although the Ottoman Foreign Ministry could not confirm Tokarzhevs'kyiKarashevych's offical position and title immediately, it should state to the Ukrainian side its readiness to sign such a protocol soon. ${ }^{122}$

Tokarzhevs'kyi-Karashevych repeated his government's desire to open a consulate in Istanbul and some other cities, on 28 March 1921 verbally 
and on 17 July 1921 with a written memorandum. ${ }^{123}$ It is not clear why Tokarzhevs'kyi-Karashevych was so insistent in seeking to open consulates for his government now in exile in the territories then onlt nominally attached (in fact, lost by the Treaty of Sèvres) to the Ottoman Empire. Whether what was left of the Ukrainian government in exile would be able to sustain such missions is another question. One can only speculate that by having (or obtaining the right to have) Ukrainian consulates in the Holy Lands Lotots'kyi or the Ukrainian government might have expected better prospects for the settlement of the question of the autocephaly of the Ukrainian Church. Whatever their motives were, the Ottoman Foreign Ministry was not inclined to grant that request, bringing to the fore, first of all, the yet confirmed diplomatic status of Tokarzhevs'kyi-Karashevych. Thus, the legal office of the Ottoman Foreign Ministry recommended to inform the Ukrainian legation verbally that the prior settlement of Tokarzhevs'kyi-Karashevych's diplomatic position would be imperative. ${ }^{124}$ In the meantime, the Ottoman Foreign Ministry gave heed to the other diplomatic precedents for the recognition of Ukraine. When the Argentinian government recognized the independence of Ukraine on 5 March 1921, this clearly gratified Ottoman diplomats who received the news through Berlin. The Ottoman Embassy in Berlin was instructed to convey this gratification to the Ukrainian legation there. ${ }^{125}$

Tokarzhevs'kyi-Karashevych stayed in Istanbul until 11 October 1921. This date most probably marks the practical end of the diplomatic mission of the Ukrainian Democratic Republic in the Ottoman Empire. Having left Istanbul, Tokarzhevs'kyi-Karashevych joined the activities of the Ukrainian government in exile in Tarnów, where he was appointed the deputy Foreign Minister. ${ }^{126}$ By this time, the Grand National Assembly government in Ankara which had assumed the political leadership of what was left of the Turkish parts of the Ottoman Empire and had effectively halted the Greek advance deep into Anatolia, came more and more to be considered as the real representative of the Anatolian Turks. The Grand National Assembly had already been recognized by some foreign states. The most important among them was Soviet Russia which deemed it expedient to support this new government in Anatolia materially against the Western Powers. Official relations were then established with the Soviet Socialist Republic of Ukraine and the Grand National Assembly of Turkey. On 13 December 1921 a Soviet Ukrainian delegation headed by the famous Marshal Mikhail Frunze in his capacity as member of the Central Executive Committee of the Soviets of Ukraine came to Ankara. ${ }^{127} \mathrm{~A}$ 'Treaty of Peace and Fraternity' was signed between Turkey (Grand National Assembly) and the Soviet Ukraine in Ankara on 2 January 1922. Among other things, article 3 of the treaty stipulated that 'all treaties concluded between Turkey and the former 
Russian Empire or between Turkey and Ukraine until 16 March 1921 did not correspond with the real mutual interests of the two parties' and therefore all such treaties were declared null and void. ${ }^{128}$ These developments betokened yet another significant step in co-operation between the Grand National Assembly of Turkey and Soviet Russia, which were so crucial especially for the former which desperately needed any support in its ongoing war of independence. To demonstrate the importance the Ankara government ascribed to this treaty, the Grand National Assembly of Turkey decided to dispatch a delegation to Kharkov (then the capital of Soviet Ukraine) headed by the Health Minister and renowned political figure Riza Nur for the exchange of the ratified texts of the Treaty. ${ }^{129}$ The Turkish delegation visited Ukraine in summer 1922. Within half a year after the 'Treaty of Peace and Fraternity' a Turkish mission was established in Kharkov and by a decision of the Central Committee of the Communist Party (Bolshevik) of Ukraine in September 1922 a diplomatic mission of the Soviet Ukraine was opened in Ankara. ${ }^{130}$ In the meantime, having inflicted a crushing defeat on the Greek forces and having acquired control of the entire Anatolian peninsula, the victorious Grand National Assembly officially abolished the monarchy which had long been reduced to a nominal existence in the Entente-occupied Istanbul on 1 November 1922.

Important as they were, these relations between Turkey (Ankara) and Soviet Ukraine which was practically not an independent state, in effect, belonged to the general context of the Turko-Soviet co-operation and, therefore, were radically different in nature from the Ottoman-Ukrainian (Ukrainian Democratic Republic) relations. Coincidentally, the latter were terminated almost at the same time as the former came into being. The formally separate relations between Turkey and the Sovict Ukraine did not last long and especially after the victorious conclusion of the Turkish War of Independence in 1922 they were eclipsed by direct Ankara-Moscow relations. In any case, with the formation of the Union of Soviet Socialist Republics in late 1922, the theoretical rights of the constituent Soviet republics to handle foreign relations were delegated to central organs, i.e. to Moscow. The details of the relations between Turkey (Ankara) and the Soviet Ukraine are beyond the scope of the present article. Yet, one may argue that Moscow's choice of inserting the Soviet Ukraine into its close relations with Turkey (Ankara) might have to do with the surviving memories of cordial Ottoman-Ukrainian relations. In spite of the fact that the representatives of Soviet Ukraine had no intention whatever of identifying themselves with the Ukrainian Democratic Republic, many a dignitary and the public in Ankara quite possibly might have had in their minds the image of independent Ukraine after Brest-Litovsk and thought that these new relations were actually a direct extension of the previous relations. 
The emergence of an independent Ukraine in the form of Ukrainian Democratic Republic was welcomed by the Ottoman Empire as an historical blessing which would symbolize the end of the centuries-old menace from the north. It was even more significant that this took place in the midst of a badly progressing war and raised the hopes of changing the tide. Turkey, together with its allies, was the first state to recognize the independence of Ukraine and sign the Treaty of Brest-Litovsk. The establishment of diplomatic relations between the two countries followed soon and made headway in a very promising atmosphere. To be sure, certain serious differences arose, such as the question of the future of the Crimea and the Crimean Tatars, as well as some other regional issues. Even then both parties indeed inferred that their common interests prevailed over their differences. A very inauspicious aspect of the Ottoman-Ukrainian relations was the epoch they were initiated. Ukrainian independent statehood had been founded on quite unstable grounds. The Ukrainian state itself could be revived from the brink of destruction thanks to the Treaty of Brest-Litovsk and the armed intervention of the Central Powers. The internal discontent stemming from foreign influence and other intrinsic and deep-rooted problems aside, the removal of the protection of the Central Powers who lost the war left the country exposed to grave threats generated by the intense armed conflicts taking place in the territory of the former Russian Empire. Thus for the greater part of 1919 and 1920, Ukrainian statehood was confined only to a fraction of its claimed territory, its seat of government changed recurrently ending up with the foreign territories, and it had to engage in an almost forlorn struggle with a variety of enemies both from within and from without. As for the Ottoman Empire, its debacle in the First World War and the Armistice of Mudros portended its final breakdown. Now it would rather operate in a capital practically under foreign occupation and with little power and would be reduced to a nominal existence. The real body politic of the Turkish state would slide to Anatolia where a burgeoning nationalist movement ended up with establishing an alternative government which would successfully undertake the consolidation and defence of what was left of the country.

Nonetheless, even under these most unfavourable circumstances when both states and governments barely enjoyed any practical and tangible existence, the diplomatic relations between the Ottoman Empire and Ukrainian Democratic Republic did not come to an abrupt end. On the contrary, Ukrainian diplomatic mission in Istanbul confronting huge difficulties persisted in functioning in the Ottoman capital under Entente occupation and did its best to represent the Ukrainian independence and its interests. It tried to function in a manner as if everything was normal. Among other things, the Ukrainian mission would assiduously work to extract 
recognition for the Ukrainian Autocephalous Church from the Patriarchate of Constantinople which itself was undergoing tense times. There were even utterly fantastic-looking enterprises of the Ukrainian mission as late as in 1921, when the Ukrainian government had long been in exile, to open consulates in such cities as Jerusalem, Aleppo, Damascus, etc. which the Ottoman Empire had long lost during the war and hardly harboured any hopes of recovering. Equally remarkably, the Ottoman Foreign Ministry also displayed a cautious but sympathetic approach toward the Ukrainian mission there and always looked for legitimate means to maintain its recognition of Ukrainian independence, under the conditions which otherwise forced Turkey to revoke all requirements and consequences of Brest-Litovsk. As both governments waned, their successors, the Grand National Assembly in Ankara and the Soviet Socialist Republic of Ukraine, resumed the relations between the two countries until the latter lost all the trappings of an independent entity with the formation of the Soviet Union. In any case, the nature of the relations between Ankara and Kharkov was assuredly different from those between Istanbul and Kiev (or wherever the seat of the Ukrainian Democratic Republic was) and, in effect, they were rather an integral part of the Turko-Soviet diplomacy. There is little doubt that relations established between the Ottoman Empire and Ukrainian Democratic Republic heralded and provided experience for renewed diplomatic ties between the republics of Turkey and Ukraine some 70 years later.

\section{NOTES}

1. The phrase'Ukrayins 'ka Narodnia Respublika' can be translated into English equally as 'Ukrainian Democratic Republic' and 'Ukrainian People's Republic', the latter being more of a verbatim translation. Throughout this article the form 'Ukrainian Democratic Republic' has been preferred, not only because this form (in French: République Démocratique Ukrainienne) was used in many an official Ukrainian document, but also in order to avoid the connotations which the term 'People's Republic' acquired subsequently.

2. For the projects and activities of Germany and Austria-Hungary during the First World War (prior to the Treaty of Brest-Litovsk), see, Jerry Hans Hoffman, 'The Ukrainian Adventure of the Central Powers, 1914-1918', Unpublished Ph. D. Dissertation, University of Pittsburgh, 1967; Oleh S. Fedyshyn, Germany's Drive to the East and the Ukrainian Revolution, 1917-1918 (New Brunswick, New Jersey, 1971), idem, "The Germans and the "Union for the Liberation of the Ukraine", 1914-1917', in Taras Hunczak (ed.), The Ukraine, 1917-1921: A Study in Revolution (Cambridge, Massachusetts, 1977), pp.305-322; Pamyatkova knizhka soyuza vyzvolennya Ukrayiny. Kalendar' na 1917 rik (Vienna, 1917); Roman Smal-Stocki, 'Actions of "Union for the Liberation of Ukraine' during World War I', The Ukrainian Quarterly, Vol.XV, No.2, pp.169-174; Helga Grebing, 'Österreich-Ungarn und die "Ukrainische Aktion' 1914-18', Jahrbücher für Geschichte Osteuropas (Munich), Vol.7, No.3 (1959), pp.270-296.

3. The representatives of the Ukrainian Rada arrived at Brest-Litovsk on 7 January 1918. John W. Wheeler-Bennett, Brest-Litovsk. The Forgotten Peace. March 1918 (London, 1963), p.166. 
4. Selami Kılıç, 'Brest-Litovsk Müzakereleri ve Banışı', Unpublished Ph.D. Dissertation, Atatürk University (Erzurum, 1995), pp.244-245.

5. 'From Talât Pasha to Enver Pasha, I February 1918', in Tülây Duran, 'I. Dünya Savaşı Sonunda Türk Diplomasisinin İlk Başarısı Brest-Litovsk Hazılıkları, III', Belgelerle Türk Tarihi Dergisi (Istanbul), No.70 (July 1973), pp.31-32. As a matter of fact, by the time Talât Pasha received an urgent request for help from the Crimean Tatar National Government, the latter had already (during the second half of January 1918) succumbed to the Bolshevik military power and the Crimean peninsula had fallen under the Bolshevik rule.

6. Ibid., p.32.

7. For an English translation of the full text, see, Wheeler-Bennett, pp.392-402. The Turkish text was published in Takvîm-i Vekâŷt (Istanbul), the official gazette of Ottoman government, consecutively on $23,24,25,26,28$, and 29 September 1918 . The Treaty was signed, for the Ottoman government, by Talât Pasha, the Grand Vizier, Ahmed Nesimi Bey, Minister of Foreign Affairs, İbrahim Hakk1 Pasha, Ottoman Ambassador in Berlin and the ex-Grand Vizier, Ahmed Izzet Pasha, General of Cavalry and ex-Minister of War, for the government of the Ukrainian Democratic Republic, by Oleksander Sevryuk, Mykola Lyubins'kyi, and Mykola Levyts'kyi, all members of the Ukrainian Central Rada.

8. Wheeler-Bennett, p.399.

9. 'Sulh Meselesi Hakkında Hariciye Nâzırı'nın Beyânâtı ve Müzâkere Cereyânı, ' Meclis-i Mebusân Zabıt Cerîdesi, Üçüncü Devre-i İntihâbiyye, Dördüncü İctima, 55inci İnikad, 23 February 1918 (Istanbul), p.898.

10. 'ilk Sulh ve Netâyici', Tanin (Istanbul), 11 February 1918.

11. Akdes Nimet Kurat, Türkiye ve Rusya (Ankara, 1970), p.390; 'Ukrayna'nın Dersaadet Sefiri', Tanin, 9 April 1918; Takvîm-i Vekâyî, 30 May 1918.

12. '(Ukrayna)'nun Dersaadet Murahhasi', Tanin, 19 April 1918.

13. 'Ukrayna Heyet-i Sefâretinin Vürûdu', Tanin, 20 April 1918; 'From Pallavicini to Buriłn, Istanbul, 23 April 1918', Ereignisse in der Ukraine 1914-1922 deren Bedeutung und historische Hintergründe, Vol.III (Philadelphia, PA, 1968), pp.619-620.

14. 'Ukrayna Sefiri'nin Ziyareti', Tanin, 23 April 1918.

15. 'Türkiya-Ukrayna', Tanin, 20 Nisan 1918.

16. The Crimean Tatar nationalists who would spearhead the convocation of the Crimean Tatar Parliament had very good relations with the Ukrainian Central Rada. Leading figures among them, such as Cafer Seydahmet [Kırımer], Dr Ahmet Özenbaşlı, Ayşe İshakova, and others joined the Congress of Representatives of Nationalities, upon the invitation of the Central Rada, in Kiev on 21-8 (8-15 in the Julian calendar) September 1917. The Third Universal Declaration of the Ukrainian Central Rada, dated 20 November 1917, which proclaimed the Ukrainian Democratic Republic, also clearly excluded the Crimea from the territory of Ukraine. Not only did the Central Rada sent its representatives to greet the opening of the Kurultay, but some military cooperation between the Crimean Tatars and the Ukrainians took place in those turbulent months as well. L.P. Garcheva, 'Tsentral'naia Rada i krymskotatarskii Kurultay - Soyuzniki v bor'be s Sovnarkomom Rossii', Problemy politicheskoi istorii Kryma. Vypusk pervyi (Simferopol, 1996), pp.17-18; Osman Kemal Hatif, Gökbayrak Altunda Milli Faaliyet (Istanbul, 1918), pp.66, 83-84; For the English translations of the Third Universal, see James Bunyan - H.H. Fisher, The Bolshevik Revolution. Documents and Materials (Stanford, 1934), pp.435-437, and Taras Hunczak (ed.), The Ukraine, 1917-1921: A Study in Revolution (Cambridge, Mass., 1977), pp.387-91.

17. In fact, the Crimean Tatar leadership which was at the time literally insulated in the Crimean peninsula was desperately seeking ways to contact the Ottoman delegation at Brest-Litovsk. For this purpose, Colonel (or Major) Dr Osman Bey, a former Ottoman prisoner of war in Russia who managed to come to the Crimea, was secretly dispatched to Brest-Litovsk with a memorandum of the Crimean Tatar National Government. Cafer Seydahmet Kırımer, Bazı Hâtıralar (Istanbul, 1993), p.266. It is known that the Grand Vizier Talât Pasha received the memorandum. Kurat, p.205.

18. Cafer Seydahmet, after a very adventurous and perilous journey via Ukraine and the 
Caucasus,. reached Trabzon during the second half of March 1918. 'From Rauf [Orbay] Bey to Enver Pasha, 26 March 1918', Archives of the Directorate of Military History and Strategical Studies of the Turkish General Staff (ATASE Archives), Ankara, First World War Collection, K: 228, D: 946, Fihrist No.14/1; 'Kınm Hükûmeti Hariciye Komiseri İstanbul'a Geliyor', Sabah (Istanbul), 24 March 1918.

19. 'Cafer Seydahmet Efendi'nin Vürûdu', Âti (Istanbul), 21 April 1918; 'Kırım Hariciye ve Harbiye Müdiri Şehrimizde', Tanin, 21 April 1918.

20. 'Ilk Ukrayna Sefareti', Tanin, 20 April 1918.

21. 'Ukrayna Hareketi', Tanin, 6 May 1918.

22. Fedyshyn, p.202.

23. 'Kınm Mebuslan', İkdam, 18 June 1918

24. 'Kurım Mebuslan', Ikdam, 19 June 1918.

25. 'Kirımliların Protestosu - Kirımlılar Ukrayna'ya Cevap Veriyor', Tanin, 30 June 1918; 'Kınmlıların Haklı Bir Mukabelesi', Vakit, 30 Haziran 1918; 'Kırım Hakkında', Sabah, 30 Haziran 1918.

26. 'Kırım Murahhaslan ve Alman, Bulgar Süferâsının Beyanâtı', Âtî, 25 June 1918.

27. 'Kurım ve Ukrayna', Tanin, 30 June 1918.

28. Edige Kırımal, Der nationale Kampf der Krimtürken (Emstedten/Westfälen, 1952), p.228.

29. 'Ilk Kirım Sefiri', Atti, 2 August 1918. In fact, Cafer Seydahmet had sent Ayvazov to Istanbul without the consent of the other [especially Russian] members of the Crimean government, who would contest this appointment vehemently upon learning of it later. A. V. Mal'gin, 'Vneshnaia politika Krymskogo Kraevogo Pravitel'stva generala Sul'kevicha', Krymskii Muzei (Simferopol), No.1 (1994), p.59.

30. 'Kırım' In Teşkili - Kırım Vekil-i Resmisiyle Mülâkat', İkdam, 5 August 1918.

31. While Enver Pasha was secretly leaving Turkey immediately after the Armistice of Mudros, he called for Ayvazov and asked 40,000 Ottoman Liras back from a sum total of 100.000 Liras which the latter had been given by the Ottoman Generalissimo to be sent to the Crimea. It seems that this was the only sum Enver Pasha took with him when he left Istanbul by a German U-Boat. Muhittin Birgen, 'Itttihat ve Terakkı'de On Sene', Son Posta (Istanbul), 14 April 1937.

32. Ziynetullah Nûşirevan, 'Kırım Meselelerine Dair Bir Mülâkat', Sabah (Istanbul), 10 September 1918.

33. Fedyshyn, p.219.

34. Ibid., pp.219-24.

35. 'Memorandum of the Legal Counsel of the Sublime Porte, 15 August 1918, No.38650', Ottoman Archives of the Turkish Prime Ministry (T.C. Başbakanlık Osmanl Arşivi), Istanbul (Hereafter cited as, $B O A$ ), Hariciye Nezâreti Hukuk Müşâvirliği İstişâre Odası Evrakı Katalogu, 'Ukraynalı Harp Esirleri', No.54/4-1. Within a few days of the signing of the Treaty of Brest-Litovsk, the Ottoman Foreign Ministry discussed the official status of the Ukrainians residing in the Ottoman Empire and whether they would be treated as subjects of a hostile state any longer. It was resolved that all subjects of the former Russian Empire should be considered as subjects of a hostile state until the Treaty became formally into force, that is, when the ratifications of the Treaty were exchanged in Vienna. 'Memorandum of the Legal Counsel of the Sublime Porte, 3 March 1918, No.38383', BOA, Hariciye Nezâreti Hukuk Müşâvirliği İstişâre Odası Evrakı Katalogu, 'Ukrayna Cumhuriyeti - Müteferrik Evrak', No.106/6-1.

36. 'Ukraynalı Üserânın Sevki', Takvîm-i Vekâyî, 4 June 1918.

37. 'Memorandum of the Legal Counsel of the Sublime Porte, 15 August 1918, No.38650.' Also, 'Memorandum of the Legal Counsel of the Sublime Porte, 25 September 1918, No.38560', BOA, Hariciye Nezâreti Hukuk Müşâvirliği İstişâre Odası Evrakı Katalogu, 'Ukrayna Cumhuriyeti - Müteferrik Evrak', No.106/6-1.

38. Nikolai Nesuk, 'Ukrainsko-turetskie otnosheniia v 1918-1921 gg.', in A. Dergachyov (ed.), Ukrainskaia gosudarstvennost' $v$ XX veke: Istoriko-politologicheskii analiz (Kiev, 1996), p.215.

39. 'From Szilassy to Burián, Istanbul, 8 June 1918', Ereignisse in der Ukraine 1914-1922 deren Bedeutung und historische Hintergründe, Vol.III (Philadelphia, PA, 1968), p.620. 
40. It is known that sometime in May the Ottoman Foreign Ministry thought of appointing Fahreddin Bey, the former chargé d'affaires in St. Petersburg, as the Ambassador to Kiev. For some reason, this choice was changed in favour Ahmet Muhtar Bey. Kurat, p.390. For a biography of Ahmet Muhtar Bey (Mollaoğlu) (1870-1934), see, Hâmid Aral, Dışişleri Bakanlı̆̆l 1967 Ylllı̆gl (Ankara, 1968), pp.118-119.

41. Takvîm-i Vekâyl, 2 September 1918.

42. Kurat cites the lenghty article which appeared in Nova Rada on 14 September 1918. Kurat, p.390.

43. Ibid.

44. Abdürreşid İbrahim, 'Türkiye Cumhuriyeti'niñ Vaşington Sefir-i Kebiri Muhtar Bey'niñ Vefầt Münasebetiyle', Yaña Yapon Muhbiri (Tokyo), No.20 (1934), pp.35-6. Apart from helping the Ottoman diplomats in their work, Abdürreşid İbrahim also gave sermons regularly in the Kiev mosque. He stayed in Kiev for about a month. "Müslüman Memleketlerinde Beş Sene Seyahat. Abdürreşid İbrahim Efendi'nin Rusya, Sibirya, Türkistan ve Türkistan-1 çinî 'deki Müşâhedâtı', Tevhî̉-i Efkâr (Istanbul), 6 December 1923.

45. Takvîm-i Vekâyı, 18 July 1918.

46. Takvîm-i Vekâyı, 4 September 1918.

47. Takvîm-i Vekâyi, 14 August 1918.

48. As a matter of fact, the lack of information about Ahmet Muhtar Bey's whereabouts who was known to had long departed from Kiev and had reached Odessa to take a steamer to Istanbul created some apprehension in the Ottoman press. 'Kiyef Sefiri Muhtar Bey Nerededir?', Ikdam (Istanbul), 13 February 1919.

49. Ahmed Ferid Bey returned to Istanbul on 21 February 1919. Emel Esin, 'Ahmed Ferid Tek (1877-25.XI.1971)', Türk Kültürü (Ankara), No.110 (December 1971), p.140. Soon after his arrival in Istanbul, Ahmet Ferid Bey was interviewed by the Ottoman paper Tasvîr-i Efkâr. There, the ex-consul general gave brief information about the hard times Ukraine was then living through. He said that then there were several Ottoman citizens who could not return to Turkey since the outbreak of the previous war, as well as some one hundred Ottoman prisoners of war (officers and privates), who had been waiting in Odessa to find some means to go back home. 'Kiyef Başşehbenderinin Avdeti', Tasvîr-i Efkâr (Istanbul), 25 February 1919.

50. Aral, p.119. Ahmet Muhtar Bey was soon elected a deputy to the Ottoman Parliament, and upon the dissolution of the latter by the British occupational forces joined the nationalist movement in Ankara, where he served as the acting Minister of Foreign Affairs and in 1922 he was sent to Moscow as the Ambassador of the Turkish (Ankara) government. Kurat, p.391.

51. Kurat, pp.391-4.

52. Ibid., p.395.

53. 'Memorandum of the Legal Counsel of the Sublime Porte, 3 December 1918, No.39340', $B O A$, Hariciye Nezâreti Hukuk Müşâvirliği İstişâre Odası Evrakı Katalogu, 'Ukrayna Cumhuriyeti - Müteferrik Evrak', No.106/6-1.

54. 'From Szilassy to Burián, Istanbul, 8 June 1918', Ereignisse in der Ukraine 1914-1922 deren Bedeutung und historische Hintergründe, Vol.III (Philadelphia, PA, 1968), p.620.

55. 'Ukrayna'nın Yeni İstanbul Sefiri', Tanin, 12 June 1918.

56. 'From Chykalenko to the Ottoman Foreign Ministry, Istanbul, 26 August 1918', BOA, Hariciye Nezâreti Evrakı Mütenevvia Kısmı, No.82/34.

57. 'From Emil Egon Prince Fürstenberg to the Imperial and Royal Ministry of Foreign Affairs, Kiev, 11 October 1918', Ereignisse in der Ukraine 1914-1922 deren Bedeutung und historische Hintergründe, Vol.III (Philadelphia, PA, 1968), p.620. In September 1918, the Ukrainian government had appealed to the Ottoman Consulate General in Kiev to ask Istanbul whether the Ukrainian mission could travel to the Ottoman capital on an excursion yacht with Ukrainian naval colors. In all likelihood, the mission at issue was that of Kistyakovskii. 'Memorandum of the Legal Counsel of the Sublime Porte, 14 September 1918, No.39137', BOA, Hariciye Nezâreti Hukuk Müşâvirliği İstişâre Odası Evrakı Katalogu, 'Ukrayna Cumhuriyeti - Müteferrik Evrak', No.106/6-1. 
58. 'From Ahmed Muhtar Bey to the Ottoman Foreign Ministry, Kiev, 19 October 1918', BOA, Hariciye Nezâreti Evrakı Mütenevvia Kısmı, No.82/34.

59. 'From the Ottoman Embassy in Kiev to the Ottoman Foreign Ministry, Kiev, 19 October 1918', BOA, Hariciye Nezâreti Evrakı Mütenevvia Kısmı, No.82/34. Tohulka, who had been designated the first secretary in the embassy of Kistyakovskii, resigned and Prince Tenishev replaced him. Also, Chykalenko left his post as he was appointed to another office in Kiev. Yet, he was to come to Istanbul with the Sukovkin embassy to fix his personal affairs there. 'From the Ottoman Embassy in Kiev to the Ottoman Foreign Ministry, Kiev, 27 October 1918’, BOA, Hariciye Nezâreti Evrakı Mütenevvia Kısmı, No.82/36. See also, 'From the President of the Council of Ministers of Ukraine (Lettre de créance of Sukovkin) to the Ottoman Foreign Minister, Kiev, 26 October 1918', and 'From the Hetman of Ukraine to the Sultan, Kiev, 26 October $1918^{\prime}, B O A$, Hariciye Nezâreti Evrak1 Mütenevvia Kism1, No.82/37.

60. Takvîm-i Vekâyl, 9 November 1918. The imperial decree of the Sultan was issued on 7 November 1918. 'From the First Secretary of the Sultan to the Grand Vizier, 7 November $1918^{\prime}, B O A$, Dosya Usûlü İradeler Tasnifi, No.12/1-12 (1-2). Kurat is of course wrong as he assumes that Sukovkin [he read the Ukrainian envoy's name through the Arabic script as 'Sokrokin' or 'Sorokin'] never arrived in Istanbul and the diplomatic relations between Ottoman Empire and Ukrainian Democratic Republic came to an end. Kurat, p.390.

61. 'From Emil Egon Prince Fürstenberg to the Imperial and Royal Ministry of Foreign Affairs, Kiev, 27 October 1918', Ereignisse in der Ukraine 1914-1922 deren Bedeutung und historische Hintergründe, Vol.III (Philadelphia, PA, 1968), p.620. This information contrasts with the information of the Ottoman Embassy in Kiev which wired Istanbul that Sukovkin left Kiev on 28 October 1918 and he was supposed to take a steamer to from Odessa to Istanbul on 30 October. 'From the Ottoman Embassy in Kiev to the Ottoman Foreign Ministry, Kiev, 29 October 1918', BOA, Hariciye Nezâreti Evrakı Mütenevvia Kismi, No.82/34.

62. Oleksander Lotots'kyi, V Tsarhorodi (Warsaw, 1939), pp.33-34.

63. Alimerdan Topçibaşev, Diplomaticheskie besedy v Stambule (1918-1919 gg.) (Baku, 1994), p.121.

64. Pavlo Skoropads'kyi, Spohadi (Kiev, 1995), p.266.

65. John S. Reshetar, Jr., The Ukrainian Revolution, 1917-1918. A Study in Nationalism (New York, 1972), pp.197-8.

66. Topçibaşev, pp.49-50.

67. Lotots'kyi, p.36; Topçibaşev, p.80.

68. Ivan Tokarzhevs'kyi Karashevich, 'Oleksander Lotots'kyi yak dyplomat', in Bohdan Hoshovs'kyi (ed.), Lytsar pratsi i obov'yazku. Zbirnyk prysvyachenyi pam'yati prof. Oleksandra Lotots 'koho-Bilousenka (Toronto, 1983), p.58.

69. Lotots'kyi, p.36.

70. Ibid.

71. Takvîm-i Vekâyl, 30 November 1918; 'From the Office of the Ottoman Grand Vizier to the Ottoman Foreign Ministry, Istanbul, 27 October 1918', BOA, Hariciye Nezâreti Evrakı Mütenevvia Kısmi, No.82/37.

72. Lotots'kyi, p.34.

73. Ibid., p.36.

74. Tokarzhevs'kyi Karashevych, p.58.

75. Lotots'kyi, p.36.

76. Tokarzhevs'kyi Karashevych, p.58.

77. Ibid.

78. Lotots'kyi finds Sukovkin's claim that he had to close down the Embassy on the pretext of the lack of money unconvincing. He argues that Sukovkin had already sent back most of the mission's staff back to Ukraine in January 1919, and the 4,000 Turkish Liras which he drew from the Istanbul branch of the Russian Foreign Trade Bank would have been more than sufficient for the subsistence of the remaining officials and for their travels for a long while to come. According to Lotots'kyi, Sukovkin had paid the January and February salaries of the returned personnel and thus exhausted his resources. Lotots'kyi, p.34. 
79. 'From the President of the Directory of the Ukrainian Democratic Republic to the Ottoman Emperor Sultan, Kiev, 17 January 1918', $B O A$, Hariciye Nezâreti Evrakı Mütenevvia Kısm1, No.82/40. For a biography of Lotots'kyi, see, Bohdan Hoshovs'kyi (ed.), Lytsar pratsi $i$ obov'yazku. Zbirnyk prysvyachenyi pam'yati prof. Oleksandra Lotots'kohoBilousenka (Toronto, 1983); Dmitro Doroshenko, 'Lytsar pratsi i obov'yazku (U 40-littya naukovoy ta 45-littya literaturno-publitsystychnoy diyal'nosty prof. Oleksandra Lotots'koho)', Kalendar-Al'manakh Dnipro na zvychainyi rik 1935 (Lvov, 1935), pp.117-23.

80. Doroshenko, pp.117-21; Boris Lotocki [Lotots'kyi], 'Foreword', in Bohdan Hoshovs'kyi (ed.), Lytsar pratsi i obov'yazku. Zbirnyk prysvyachenyi pam'yati prof. Oleksandra Lotots'koho-Bilousenka (Toronto, 1983), pp.11-12.

81. Lotots'kyi, pp.10-11; Evhen Onats'kyi, 'Oleksander Lotots'kyi', Ukrayins'ka Mala Entsiklopediya (Buenos Aires), Vol.VI, p.863.

82. Lotos'kyi, pp.34-5. Serhiy Botehyns'kyi, the head of the Ukrainian government and the Foreign Minister, by telegram to the Porte from Odessa on 4 April 1919 informed the Ottoman government that Kobylyans'yi, in the capacity of the chargé d'affaires, was to exercise the functions of the president of the mission in the absence of Lotots'kyi. 'From Serhiy Botehyns'kyi to the Sublime Porte, Odessa, 4 April 1919', BOA, Hariciye Nezâreti Evrakı Mütenevvia Kısmı, No.82/39.

83. Ikdam wrote: 'The Ukrainian embassy which had suspended its functioning due to its failure to receive necessary funds from its government has been reopened for the last couple of days. Until the arrival to our town of Monsieur Lotots'kyi, who has been appointed the Ukrainian ambassador, General Kobylyans'kyi will act as the consul general and deputy ambassador.' 'Ukrayna Sefarethanesi', İkdam (Istanbul), 21 April 1919.

84. Lotots'kyi, p.35.

85. Tokarzhevs'kyi-Karashevych, p.59.

86. Lotos'kyi, pp.16-17.

87. Ibid., pp.35-7.

88. Ibid., pp.38-9.

89. Ibid., pp.39-40.

90. Among those who stayed were P. E. Chykalenko (Secretary), V. P. Prykhodko, O. Kovalenko, M. Kovals'kyi, Colonel V. Kedrovs'kyi (military attaché), General Ostafiyiv, V. Radzimovs'kyi (legal adviser), P. Linkevych (courier), and V. Zhelehivs'kyi (courier). Ibid., p.12.

91. Ibid., p.37.

92. Ibid., pp.49 and 155 .

93. Ibid., pp.51-4 and 156-7.

94. Ibid., pp.173-4.

95. Ibid., pp.44 and 153-4.

96. Ibid., p.46.

97. Ibid., pp.158-9. The Entente handovers of ex-prisoners of war to Bolsheviks were not always a result of dereliction and carelessness. In return for ex-prisoners of war, Bolsheviks released Entente citizens or Russian nationals who were detained by them. In the abovementioned event, some 100 such men were taken from the Bolsheviks in Odessa and none in Ochakov. Ibid., p.46.

98. 'Translation of the postscript of the Legal Counsel of the Sublime Porte, 20 September 1918, No.40074.' BOA, Hariciye Nezâreti Hukuk Müşâvirliği İstişâre Odası Evrakı Kataloğu, 'Ukraynalı Harp Esirleri', No.154/4-1.

99. Lotots'kyi, pp.159-62. He warned the Ottoman government about the invalidity of such notes then in circulation in Istanbul with a memorandum to the Ottoman Foreign Ministry on 13 February 1920. Ibid., p.161.

100. Alexis Alexandris, The Greek Minority of Istanbul and Greek-Turkish Relations 1918-1974 (Athens, 1992), p.55.

101. Lotots'kyi, pp.86-8 and 97.

102. Alexandris, pp.54-62.

103. Lotots'kyi, pp.94-8. 
104. Indeed, during the second half of 1917 both France and Britain endeavoured to monitor the developments in Ukraine by sending their officials there and established direct and friendly contacts with the newly emerging Ukrainian institutions and politicians. These contacts continued and even formalized after the declaration of the Ukrainian national state (though still nominally within the Russian Republic) by the Third Universal. While France appointed General Tabouis as the Commissioner in Ukraine on 29 December 1917, Britain appointed Picton Bagge as the British Representative in Ukraine in January 1918. Upon the Central Rada's joining the peace negotiations at Brest-Litovsk, the frustrated Entente representatives washed their hands of Ukraine. Isidore Nahayewsky, History of the Modern Ukrainian State 1917-1923 (Munich, 1966), pp.214-16, 251-3.

105. Lotots'kyi, p.66.

106. Ibid., pp.67-70.

107. Ibid., pp.72 and 167.

108. Ibid., pp.72, 168-71.

109. Ibid., p.73.

110. Ibid., pp.77-9.

111. Ibid., pp.110-11. Tokarzhevs'kyi-Karashevych states that they were unable to publish further pamphlets due to the want of money. Tokarzhevs'kyi-Karashevych, p.61.

112. Lotots'kyi, pp.104-10.

113. 'Ukrayna Sefiriyle Mülâkat', Ifham (Istanbul), 4 September 1919.

114. 'Kiyef'i Kim Aldı?', If ham, 10 September 1919.

115. Lotots'kyi, pp.133-6; Tokarzhevs'kyi-Karashevych, p.59.

116. Lotots'kyi, p.138.

117. Ibid., pp.140-2.

118. Yan Tokarzhevs'kyi-Karashevych (1885-1954) was a Podolian aristocrat and a famous historian. See, Evhen Onats'kyi, 'Kn. Yan Tokarzhevs'kyi-Karashevych', Ukrayins'ka Mala Entsyklopediya, Vol.XII (Buenos Aires, 1963), p.1910.

119. 'Memorandum of the Legal Counsel of the Sublime Porte, 11 May 1920, No.40613', BOA, Hariciye Nezâreti Hukuk Müşâvirliği İstişâre Odası Evrakı Katalogu, 'Ukrayna Cumhuriyeti - Müteferrik Evrak', No.106/6-1.

120. Lotots'kyi, p.172.

121. 'Memorandum of the Legal Counsel of the Sublime Porte, 11 May 1920, No.40613', BOA, Hariciye Nezâreti Hukuk Müşâvirliği İstişâre Odası Evrakı Katalogu, 'Ukrayna Cumhuriyeti - Müteferrik Evrak', No.106/6-1.

122. 'Memorandum of the Legal Counsel of the Sublime Porte, 11 April 1921, No.41724', BOA, Hariciye Nezâreti Hukuk Müşâvirliği İstişâre Odası Evrakı Katalogu, 'Ukrayna Cumhuriyeti - Müteferrik Evrak', No.106/6-1. The Treaty of Sèvres was never ratified by the Sultan and at any rate the nominal existence of the Ottoman Empire came to an end following the military victory of the Grand National Assembly government in Ankara which had categorically condemned the Treaty of Sèvres in late 1922.

123. 'Memorandum of the Legal Counsel of the Sublime Porte, 22 July 1921, nos. 41718-41940', BOA, Hariciye Nezâreti Hukuk Müşâvirliği İstişâre Odası Evrakı Katalogu, 'Ukrayna Cumhuriyeti - Müteferrik Evrak', No.106/6-1.

124. Ibid.

125. 'Memorandum of the Legal Counsel of the Sublime Porte, 27 July 1921, No.41835', BOA, Hariciye Nezâreti Hukuk Müşâvirliği İstişâre Odası Evrakı Katalogu, 'Ukrayna Cumhuriyeti - Müteferrik Evrak', No.106/6-1.

126. Onats'kyi, p.1910.

127. 'Ukrayna Heyet-i Mahsûsası Şehrimizde', Hakimiyet-i Milliyye (Ankara), 14 December 1921.

128. For the full text of this 'Treaty of Peace and Fraternity between Turkey and Ukraine' in French and Turkish, see, Traité d'Amitié et de Fraternité entre la Turquie et l'Ukraine signé a Angora le 2 Janvier 1922. Türkiye ve Ukrayna Muhâdenat ve Uhuvvet Muahedenâmesi (Ankara'da 2 Kânûn-u Sânî 1338-1922 Tarihinde İmza Edilmiştir) (Istanbul, 1923). A quite interesting sign of accommodating political jargon with the Soviets was that the title of Yusuf Kemal Bey was stated not as the 'Foreign Minister' (Hariciye Vekili) as it had 
been normally the case, but in the form of the 'Foreign Commissar' (Hariciye Komiseri). So was the case in its French translation ('Commissaire des Affaires Etrangères').

129. 'Ukrayna Muahedesini Teati İçin Harkof'a Gidecek Heyet Hakkında İcra Vekilleri Heyeti Riyaseti Tezkeresi', T.B.M.M. Zabit Ceridesi, Vol.XVIII (Ankara, 1959), pp.265-70.

130. Stanislav Vladiyslavovych Kul'chyts'kyi, 'Yak vyrishuvalosya "Ukrayins'ke pytannya",' Polityka $i$ Chas (Kiev), No.11 (1994), pp.68-9. 